\title{
Investigation of Soil Liquefaction Potential around Efteni Lake in Duzce Turkey: Using Empirical Relationships between Shear Wave Velocity and SPT Blow Count $(N)$
}

\author{
Ali Ateş, ${ }^{1}$ İnan Keskin, ${ }^{2}$ Ermedin Totiç, ${ }^{3}$ and Burak Yeşil ${ }^{4}$ \\ ${ }^{1}$ Geotechnical Division, Department of Civil Engineering, Duzce University, 81620 Duzce, Turkey \\ ${ }^{2}$ Geotechnical Division, Department of Civil Engineering, Karabuk University, 78050 Karabuk, Turkey \\ ${ }^{3}$ Geotechnical Division, Department of Civil Engineering, Bartin University, 74100 Bartin, Turkey \\ ${ }^{4}$ Duzce Technical Science Vocational School Construction Division, Duzce University, 81620 Duzce, Turkey
}

Correspondence should be addressed to Ali Ateş; aliates@duzce.edu.tr

Received 7 January 2014; Accepted 19 May 2014; Published 1 July 2014

Academic Editor: Gonzalo Martínez-Barrera

Copyright (@ 2014 Ali Ateş et al. This is an open access article distributed under the Creative Commons Attribution License, which permits unrestricted use, distribution, and reproduction in any medium, provided the original work is properly cited.

\begin{abstract}
Evaluation of the liquefaction potential of a liquefaction-prone area is important for geotechnical earthquake engineering, both for assessment for site selection and for planning and new constructions. The liquefaction potential index for the city of Duzce in northwestern Turkey using the empirical relationships between the Standard Penetration Test (SPT) and the Shear Wave Velocity Test $\left(V_{S}\right)$ was investigated in this study. After, $V_{S}$ values based on SPT blow counts $(N)$ were obtained from the alluvial soils in the city of Duzce. The liquefaction potential indexes of the soils were determined using the empirical relationships between the Standard Penetration Test (SPT) and the Shear Wave Velocity Test $\left(V_{S}\right)$ calculating for a probable earthquake of $M_{W}=7.2$. In the result of the study, the liquefaction potential index (LPI) values were interpreted and compared evaluating the SPT $N$ blow count values obtained from the study area. Based on the empirical relationships assumed for the soils, it was observed that there was not a perfect agreement between the results of the two methods. The liquefaction potential index values using the SPT $N$ blow counts were found to be lower than those of the $V_{S}$ method.
\end{abstract}

\section{Introduction}

The liquefaction resistance of soils can be evaluated using laboratory tests such as the cyclic simple shear and cyclic triaxial and cyclic torsional shear tests. Additionally, field methods such as the Standard Penetration Test (SPT), Cone Penetration Test $(\mathrm{CPT})$, and Shear Wave Velocity Test $\left(V_{S}\right)$ can be employed. The occurrence of liquefaction in soils is often evaluated using the simplified procedure originally developed and proposed by Seed and Idriss [1] based on the SPT blow counts correlated with the cyclic stress ratio (CSR), a parameter representing the seismic loading on the soil. This procedure has undergone several revisions and updates [2-4]. In addition to these, procedures have been developed based on the Cone Penetration Test (CPT), Becker Penetration Test (BPT), and small-strain Shear Wave Velocity $\left(V_{S}\right)$ measurements. Youd et al. [2] provided and enhanced a recent review of the Seed and Idriss simplified procedure and the in situ test methods commonly used to evaluate the liquefaction resistance of soils.

The use of $V_{S}$ to determine the liquefaction resistance is influenced by factors such as confining stress, plasticity, and relative density [5-7]. In situ $V_{S}$ can be measured by several seismic tests, including cross hole, down hole, seismic cone penetrometer (SCPT), suspension logger, and spectral analysis of the surface waves (SASW) [8].

During the past two decades, several procedures have been proposed to estimate liquefaction resistance based on $V_{S}$ [8]. These procedures were developed from laboratory studies [8-15], analytical studies $[16,17]$, penetration $V_{S}$ equations $[18,19]$, and in situ $V_{S}$ measurements at earthquake sites [2022]. Some of these procedures follow the general approach of the Seed-Idriss simplified procedure, in which the $V_{S}$ is corrected with the cyclic stress ratio. This paper presents 


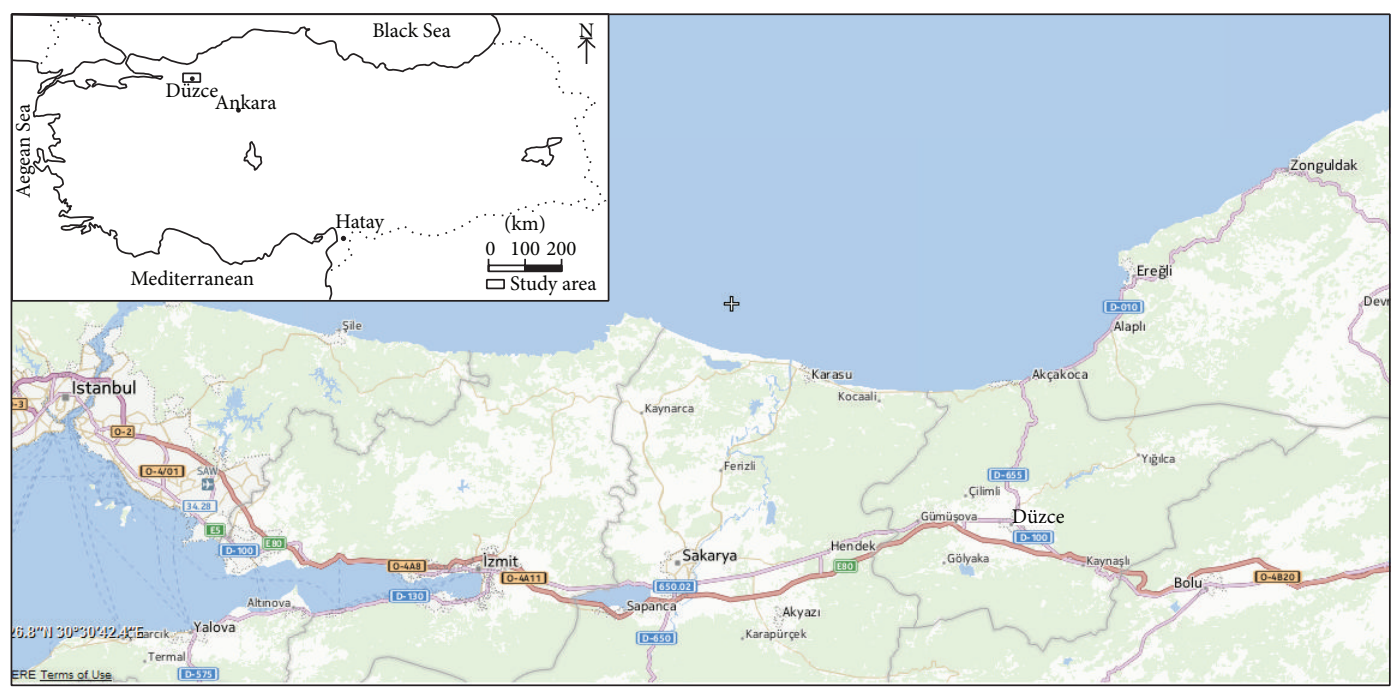

Figure 1: The study area (Duzce Province).

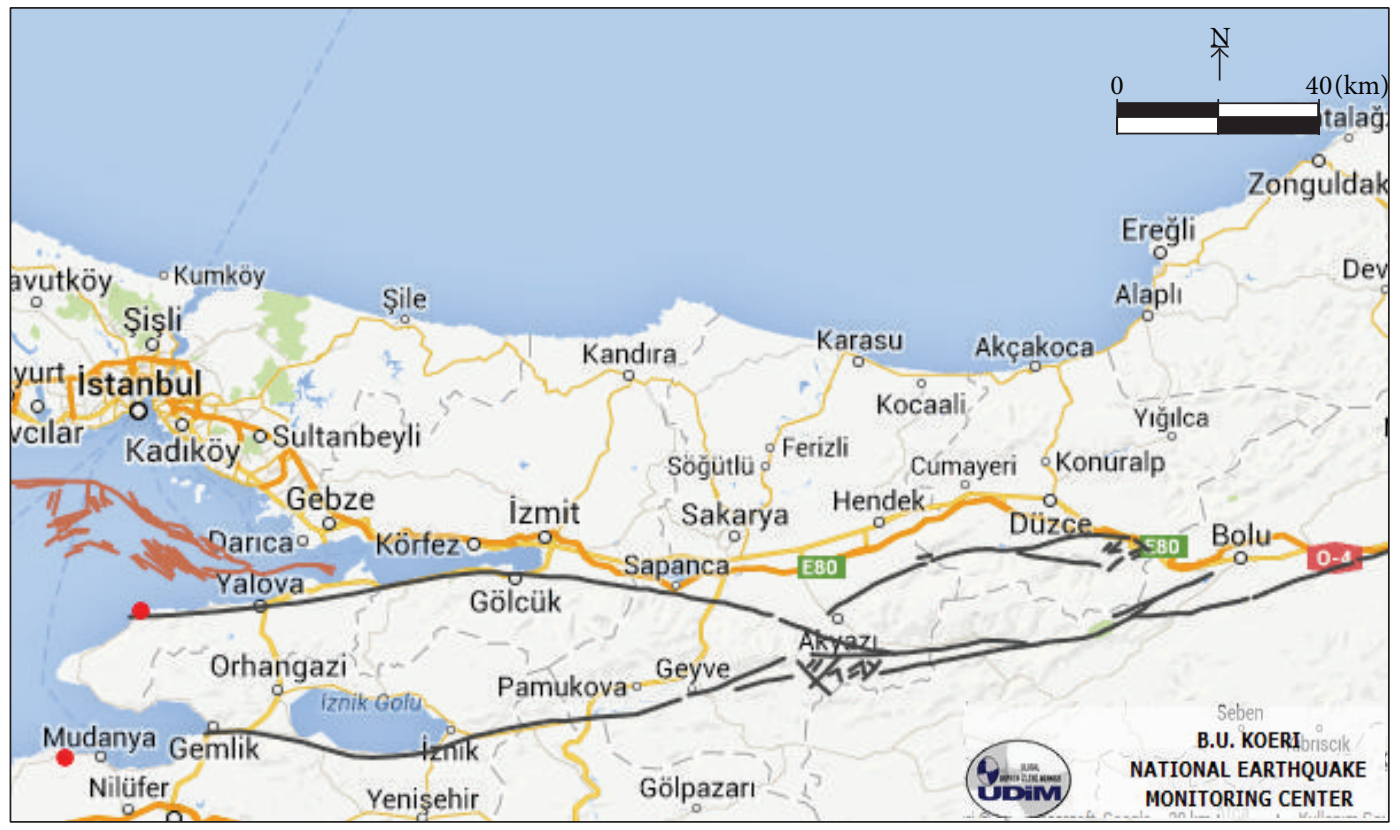

Figure 2: View of the Duzce fault [24].

the results of the comparison between the $V_{S}$ and SPT methods of soil liquefaction potential evaluation carried out in Duzce Province in Turkey. Furthermore, the liquefaction potential indexes (LPI) for both aforementioned methods were calculated using the procedure of Iwasaki et al. [23].

\section{Study Area}

Duzce Province is located in northwestern Turkey (Figure 1). It is under the effect of the North Anatolian Fault Zone (NAFZ) and is about $30 \mathrm{~km}$ distant from the Black Sea. The provincial capital of Duzce is situated on an alluvial soil site.

2.1. Geomorphological and Geological Setting. The study area is situated in an active seismic earthquake zone [24]. Duzce has been affected by the active faults. The 1957 Bolu $(M=7)$ and 1967 Adapazarı $(M=7.1)$ earthquakes occurred on the Bolu-Abant Dokurcun segments of the NAFZ. The active and probable active faults of Duzce, Hendek, and Çilimli are in close proximity to the study area [25] (Figure 2).

During the $(M=7.4)$ earthquake of 1999 , the $30 \mathrm{~km}$ eastern segment of the $130 \mathrm{~km}$ fault rupture occurred on the western part of the Duzce Fault reaching to Efteni Lake [25]. Duzce plain is an active subsidence and deposition area controlled by lateral strike slip faults surrounded by pre-Quaterney-aged rocks. The oldest is the Yığllca Unit of Eocene-aged caycuma. Formations include volcanic sandstone, rottenstone, andestic and basaltic lavas and volcanic breccia [26]. Quaternary-aged fan, deltaic, and marsh type 

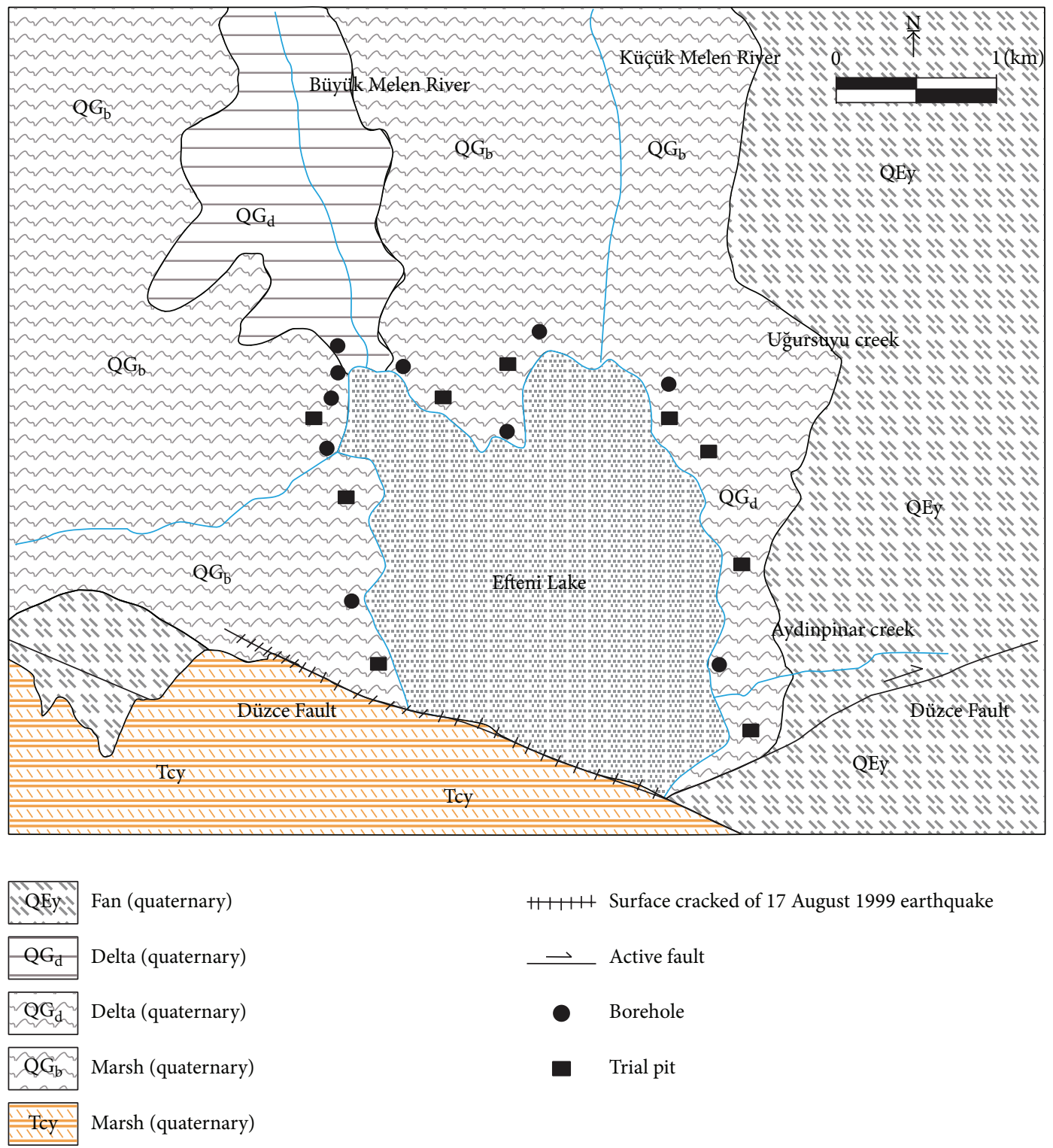

Figure 3: Geological map of the study area and some borehole locations [26].

deposits cover this unit, which consists of gravel, sand, silt, and clay material (Figure 3).

Due to the elevation of the surrounding rocks and as a result of the basin drainage, deposition occurred mostly in the Duzce area and its surroundings (Figure 4). Little Melen (Kucuk Melen) River discharges into the lake and continues flowing towards the only discharge from the lake, the Big Melen (Buyuk Melen) River. In addition, Aksu, Ugursuyu and Aydinpınar Creeks deposit alluvial fans and join in the lake basin. The surrounding rocks are extremely weathered by eroding, allowing the increase in sedimentation. The thickness of the sedimentation is about $260-300 \mathrm{~m}$. The deposition areas have displaced laterally and the horizontal stratigraphy has been altered [25] (Figure 4).

2.2. Seismotectonics of the Study Area. Duzce plain is a pull apart type basin that is controlled by the lateral strike slip fault

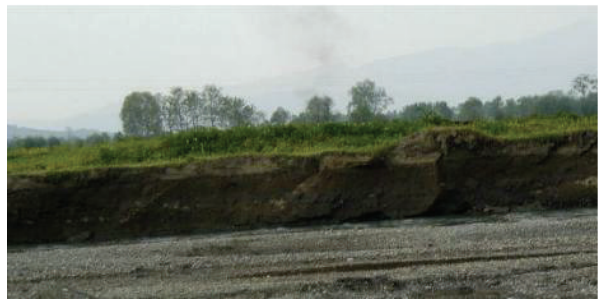

FIgURE 4: View of the deposits in the Duzce area.

system in the NAFZ [28] (Figure 5). Paleo- and neotectonic period active faults exist at the north and south of the plain. There are several faults which are parallel and oblique to these major faults. During the 12 November 1999's earthquake, the surface rupture ranged through Golyaka on the south towards Kaynaşlı on the east, ending in the Asarsu Valley and 
TABLE 1: Magnitude and damage records of earthquakes around the study area [24].

\begin{tabular}{|c|c|c|c|c|c|c|}
\hline Locations & Date & Epicenter & $M_{w}$ & Total damage on structures & Death & Injury \\
\hline Murefte & 09.08 .1912 & $40.60-27.20$ & 7.3 & 5.540 & 216 & 466 \\
\hline Hendek & 20.06 .1943 & $40.85-30.51$ & 6.6 & No & 336 & No \\
\hline Gerede & 01.02 .1944 & $41.41-32.69$ & 7.2 & 20.865 & 3.959 & No \\
\hline Duzce & 10.02.1944 & $41.00-32.30$ & 5.4 & 900 & No & No \\
\hline Mudurnu & 05.04 .1944 & $40.84-31.12$ & 5.6 & 900 & 30 & No \\
\hline Yenice & 18.03 .1953 & $39.99-27.36$ & 7.4 & 9.670 & 265 & 336 \\
\hline Abant & 26.05.1957 & $40.60-31.20$ & 7.1 & 4.201 & 52 & 100 \\
\hline Çınarcık & 18.09.1963 & $40.77-29.12$ & 6.3 & 230 & 1 & 26 \\
\hline Adapazarı & 22.07.1967 & $40.60-30.89$ & 7.2 & 5.569 & 89 & 235 \\
\hline Gelibolu & 27.03 .1975 & $40.45-26.12$ & 6.4 & 980 & 7 & No \\
\hline Golcuk & 13.09.1999 & $40.80-30.03$ & 5.7 & No & No & Unknown \\
\hline Duzce & 12.11.1999 & $40.79-31.21$ & 7.2 & 15.389 & 845 & 4.948 \\
\hline Bolu & 17.11.1999 & $40.83-31.51$ & 5.0 & No & No & No \\
\hline Bolu & 22.03 .2000 & $40.94-31.58$ & 5.4 & No & No & No \\
\hline Yigilca & 26.08 .2001 & $40.93-31.53$ & 5.1 & No & No & No \\
\hline
\end{tabular}

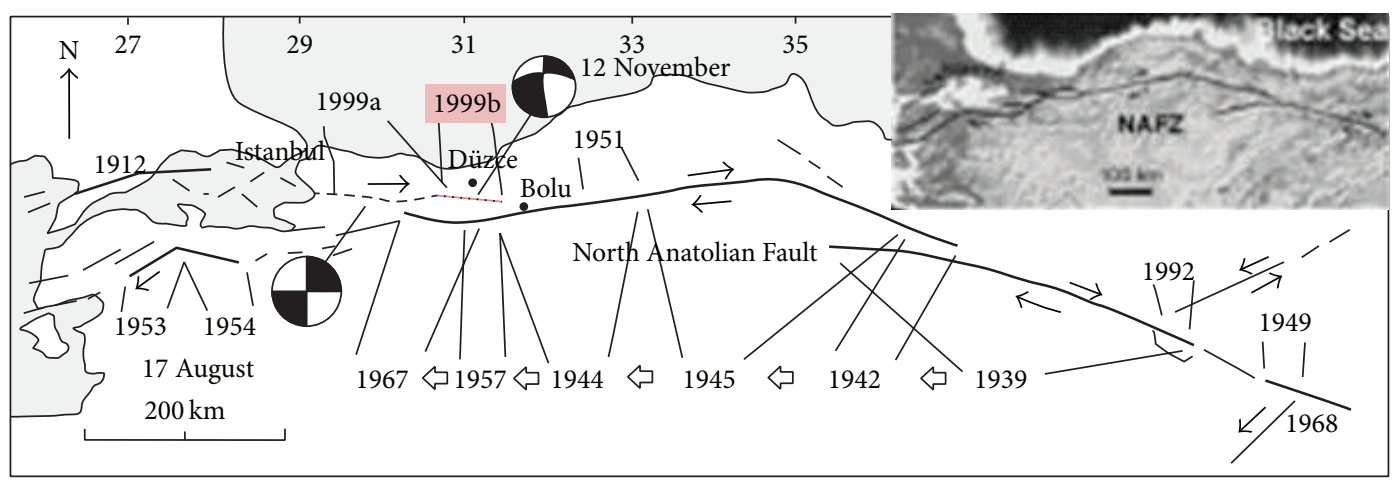

FIGURE 5: Epicenters of the earthquakes and historical earthquakes in the region [25].

the Bolu Tunnel. The city of Duzce is situated in the middle of the plain on a pressure ridge type hill, probably tectonically controlled. Major earthquake records are given in Table 1. Historical earthquakes have been recorded on the AbantBayramoren segment in the south. There were 12 earthquakes between 1967 and 1890. The great earthquake of 17 August, $1668\left(M_{S}=8\right)$, caused a disaster in Anatolia [29], with aftershocks continuing for 6 months [30]. The Bolu-Gerede earthquake $\left(M_{w}=7.3\right)$ on January 2, 1944, was a major one, recorded after the implementation of instruments for scientific measurement of magnitude. It was noted that 2,381 people died and 50,000 houses were damaged [31]. Although the 17 August, 1999, Marmara and 12 November, 1999, Duzce earthquakes occurred on the western segment of the North Anatolian Fault, the measured average value of the horizontal ground acceleration was $0.54 \mathrm{~g}$ in Duzce [32].

\section{Materials and Methods}

3.1. Field Investigations. Geotechnical bore holes were drilled at 40 locations. The depths of the boreholes ranged from 10 to $30 \mathrm{~m}$, which measured to a total of $296 \mathrm{~m}$. These boreholes were utilized to determine the consistency of fine-grained soils and the stiffness of the coarse soils, to obtain undisturbed and disturbed samples and to measure the groundwater level. A Standard Penetration Test (SPT) [33] was carried out during the drillings and SPT N blow counts were obtained in the boreholes. In situ unit weight and moisture content values were obtained from the trial pits. Then, representative soil samples were obtained in order to determine the geomechanical properties of the soils. The 296 m-thick alluvium was very heterogeneous and included confined and umconfined aquifers. The groundwater level was mostly at the surface and ranged between 1.5 and $3.9 \mathrm{~m}$.

In this study, the shear wave velocity $\left(V_{S}\right)$ measurements were based on Andrus et al. [27] process for assessing liquefaction potential; $V_{S}$ values were calculated using empirical equations between shear wave velocity and SPT blow count $(N)$ for all types as follows [34]. The $V_{S}$ values based on SPT blow count $(N)$ were given below (Table 2$)$ :

$$
\begin{gathered}
V_{S}=61 \cdot N^{0.5}, \\
V_{S}=97 \cdot N^{0.314}, \\
V_{S}=76 \cdot N^{0.33}, \\
V_{S}=121 \cdot N^{0.27}, \\
V_{S}=22 \cdot N^{0.85} .
\end{gathered}
$$


TABle 2: Field data of Duzce Province.

\begin{tabular}{|c|c|c|c|c|c|c|c|c|}
\hline \multirow[b]{2}{*}{$\begin{array}{l}\text { Boreholes } \\
\text { number }\end{array}$} & \multirow[b]{2}{*}{$\begin{array}{l}\text { SPT-N } \\
\text { Depth (m) }\end{array}$} & \multirow[b]{2}{*}{ SPT- $N$} & \multirow[b]{2}{*}{ Water Level } & \multicolumn{5}{|c|}{ Shear Wave Velocity } \\
\hline & & & & $\begin{array}{c}\text { Equation (1) } \\
\left(61 \cdot N^{0.5}\right)\end{array}$ & $\begin{array}{c}\text { Equation (2) } \\
\left(97 \cdot N^{0.314}\right)\end{array}$ & $\begin{array}{c}\text { Equation (3) } \\
\left(76 \cdot N^{0.33}\right)\end{array}$ & $\begin{array}{l}\text { Equation (4) } \\
\left(121 \cdot N^{0.27}\right)\end{array}$ & $\begin{array}{c}\text { Equation (5) } \\
\left(22 \cdot N^{0.85}\right)\end{array}$ \\
\hline BH1 & 3 & 32 & 3.5 & 345.06 & 287.99 & 238.5 & 308.45 & 418.7 \\
\hline BH1 & 9 & 32 & 3.5 & 435.06 & 287.99 & 238.5 & 308.45 & 418.7 \\
\hline $\mathrm{BH} 2$ & 3 & 25 & 3 & 305 & 265.5 & 219.9 & 288.6 & 339.4 \\
\hline $\mathrm{BH} 2$ & 6 & 15 & 3 & 236.3 & 227.02 & 185.75 & 251.4 & 219.9 \\
\hline $\mathrm{BH} 2$ & 15 & 45 & 3 & 409.2 & 320.5 & 266.9 & 338.2 & 559.3 \\
\hline $\mathrm{BH} 3$ & 4.5 & 32 & 4.00 & 345.06 & 227.02 & 185.75 & 251.4 & 219.9 \\
\hline $\mathrm{BH} 3$ & 6.00 & 32 & 4.00 & 345.06 & 227.02 & 185.75 & 251.4 & 219.9 \\
\hline BH3 & 7.5 & 28 & 4.00 & 322.8 & 276.17 & 228.4 & 297.52 & 373.7 \\
\hline BH3 & 12 & 31 & 4.00 & 339.7 & 285.14 & 236.02 & 305.9 & 407.5 \\
\hline $\mathrm{BH} 4$ & 3.00 & 31 & 2.5 & 339.7 & 285.14 & 236.02 & 305.9 & 407.5 \\
\hline $\mathrm{BH} 4$ & 6.00 & 13 & 2.5 & 219.95 & 217.01 & 177.2 & 241.9 & 194.7 \\
\hline BH4 & 7.5 & 16 & 2.5 & 244 & 231.7 & 189.8 & 255.8 & 232.3 \\
\hline BH4 & 9.00 & 13 & 2.5 & 219.94 & 217.1 & 177.2 & 242 & 194.6 \\
\hline BH4 & 17.00 & 13 & 2.5 & 219.94 & 217.1 & 177.2 & 242 & 194.6 \\
\hline BH5 & No & No & No & No & No & No & No & No \\
\hline BH6 & 3.00 & 28 & 2.5 & 322.8 & 276.2 & 228.24 & 297.52 & 373.7 \\
\hline BH6 & 4.5 & 23 & 2.5 & 292.54 & 260 & 213.9 & 282.2 & 316.2 \\
\hline BH6 & 7.5 & 21 & 2.5 & 279.6 & 252.3 & 207.56 & 275.3 & 292.7 \\
\hline BH6 & 12.00 & 32 & 2.5 & 345.06 & 252.3 & 207.56 & 275.3 & 292.7 \\
\hline BH7 & No & No & No & No & No & No & No & No \\
\hline BH8 & 9.00 & 11 & 4.0 & 202.3 & 206 & 167.7 & 231.2 & 168.9 \\
\hline BH8 & 10.50 & 26 & 4.0 & 311.1 & 269.9 & 222.7 & 292 & 350.9 \\
\hline BH8 & 13.500 & 28 & 4.0 & 322.8 & 276.2 & 228.24 & 297.52 & 373.7 \\
\hline BH9 & 9.00 & 28 & 4.00 & 322.8 & 276.2 & 228.24 & 297.52 & 373.7 \\
\hline BH9 & 16.5 & 81 & 4.00 & 549 & 385.6 & 324.1 & 396.4 & 922 \\
\hline $\mathrm{BH} 10$ & No & No & No & No & No & No & No & No \\
\hline BH11 & 7.5 & 14 & 3.5 & 228.3 & 222.2 & 182 & 246.7 & 207.4 \\
\hline BH11 & 10.5 & 40 & 3.5 & 386 & 308.9 & 256.7 & 327.6 & 506.1 \\
\hline BH12 & 4.5 & 32 & 3.25 & 345.1 & 252.3 & 207.56 & 275.3 & 292.7 \\
\hline BH12 & 6.0 & 36 & 3.25 & 366 & 298.9 & 248 & 318.5 & 463 \\
\hline BH12 & 10.5 & 42 & 3.25 & 395.4 & 313.7 & 260.9 & 331.9 & 527.8 \\
\hline BH13 & No & No & No & No & No & No & No & No \\
\hline BH14 & 3.0 & 15 & 3.5 & 236.3 & 227.02 & 185.8 & 251.4 & 219.9 \\
\hline BH14 & 4.5 & 37 & 3.5 & 372 & 302 & 250.1 & 320.8 & 473.6 \\
\hline BH14 & 6 & 26 & 3.5 & 132.6 & 269.9 & 222.8 & 291.7 & 350.9 \\
\hline BH14 & 7.5 & 30 & 3.5 & 334.5 & 282.3 & 233.5 & 303.2 & 396.7 \\
\hline BH15 & No & No & No & No & No & No & No & No \\
\hline BH16 & 4.5 & 22 & 2.5 & 286.2 & 256.1 & 210.8 & 278.8 & 304.5 \\
\hline BH17 & 3.0 & 13 & 3.5 & 219.94 & 217.1 & 177.2 & 242 & 194.6 \\
\hline BH17 & 4.5 & 10 & 3.5 & 192.9 & 199.9 & 162.5 & 225.4 & 155.8 \\
\hline BH17 & 6.0 & 21 & 3.5 & 279.6 & 252.3 & 207.56 & 275.3 & 292.7 \\
\hline BH17 & 7.0 & 26 & 3.5 & 311.1 & 269.9 & 222.7 & 292 & 350.9 \\
\hline BH18 & 15 & 34 & 4.5 & 355.7 & 293.6 & 243.4 & 313.6 & 440.1 \\
\hline BH19 & 3.0 & 13 & 3 & 219.94 & 217.1 & 177.2 & 242 & 194.6 \\
\hline BH19 & 4.5 & 18 & 3 & 258.9 & 240.1 & 197.3 & 264.1 & 256.7 \\
\hline
\end{tabular}


TABle 2: Continued.

\begin{tabular}{|c|c|c|c|c|c|c|c|c|}
\hline \multirow[b]{2}{*}{$\begin{array}{l}\text { Boreholes } \\
\text { number }\end{array}$} & \multirow[b]{2}{*}{$\begin{array}{l}\text { SPT-N } \\
\text { Depth (m) }\end{array}$} & \multirow[b]{2}{*}{ SPT-N } & \multirow[b]{2}{*}{ Water Level } & \multicolumn{5}{|c|}{ Shear Wave Velocity } \\
\hline & & & & $\begin{array}{c}\text { Equation (1) } \\
\left(61 \cdot N^{0.5}\right)\end{array}$ & $\begin{array}{c}\text { Equation (2) } \\
\left(97 \cdot N^{0.314}\right)\end{array}$ & $\begin{array}{c}\text { Equation (3) } \\
\left(76 \cdot N^{0.33}\right)\end{array}$ & $\begin{array}{c}\text { Equation (4) } \\
\left(121 \cdot N^{0.27}\right)\end{array}$ & $\begin{array}{c}\text { Equation (5) } \\
\left(22 \cdot N^{0.85}\right)\end{array}$ \\
\hline BH19 & 7.5 & 25 & 3 & 305 & 266.6 & 219.9 & 288.6 & 339.4 \\
\hline BH19 & 13.5 & 27 & 3 & 317 & 273 & 255.6 & 294.9 & 362.4 \\
\hline $\mathrm{BH} 20$ & No & No & No & No & No & No & No & No \\
\hline $\mathrm{BH} 21$ & No & No & No & No & No & No & No & No \\
\hline $\mathrm{BH} 22$ & No & No & No & No & No & No & No & No \\
\hline $\mathrm{BH} 23$ & 4.5 & 29 & 2.0 & 328.5 & 279.3 & 230.8 & 300.35 & 385.1 \\
\hline $\mathrm{BH} 23$ & 9.0 & 8 & 2.0 & 172.6 & 186.4 & 8.96 & 212.2 & 128.9 \\
\hline $\mathrm{BH} 23$ & 10.5 & 10 & 2.0 & 192.9 & 199.9 & 162.5 & 225.4 & 155.8 \\
\hline $\mathrm{BH} 23$ & 13.5 & 9 & 2.0 & 183 & 194 & 157 & 219 & 142.5 \\
\hline $\mathrm{BH} 23$ & 15.0 & 12 & 2.0 & 211.4 & 211.7 & 172.6 & 236.7 & 181.9 \\
\hline $\mathrm{BH} 24$ & 7.5 & 14 & 3.5 & 228.3 & 222.2 & 182 & 246.7 & 207.4 \\
\hline $\mathrm{BH} 24$ & 10.5 & 40 & 3.5 & 385.8 & 308.9 & 256.8 & 327.6 & 506.1 \\
\hline BH 25 & 3.0 & 44 & 4.5 & 404.7 & 318.3 & 264.9 & 336.2 & 548.8 \\
\hline BH25 & 4.5 & 14 & 4.5 & 228.3 & 222.2 & 182 & 246.7 & 207.4 \\
\hline $\mathrm{BH} 25$ & 7.5 & 9 & 4.5 & 183 & 194 & 157 & 219 & 142.5 \\
\hline $\mathrm{BH} 25$ & 10.5 & 19 & 4.5 & 265.9 & 244.6 & 200.9 & 267.9 & 268.9 \\
\hline $\mathrm{BH} 25$ & 12.0 & 22 & 4.5 & 286.2 & 256.1 & 210.8 & 278.8 & 304.5 \\
\hline BH26 & 6.0 & 13 & 2.0 & 219.94 & 217.1 & 177.2 & 242 & 194.6 \\
\hline $\mathrm{BH} 26$ & 9.0 & 32 & 2.0 & 345.1 & 252.3 & 207.56 & 275.3 & 292.7 \\
\hline BH27 & NO & No & No & No & No & No & No & No \\
\hline BH28 & No & No & No & No & No & No & No & No \\
\hline BH 29 & 7.5 & 27 & 3.5 & 317 & 273 & 255.6 & 294.9 & 362.4 \\
\hline BH29 & 10.5 & 23 & 3.5 & 292.54 & 260 & 213.9 & 282.2 & 316.2 \\
\hline BH 29 & 12.0 & 50 & 3.5 & 431.2 & 331.2 & 276.4 & 347.95 & 612 \\
\hline ВH30 & No & No & No & No & No & No & No & No \\
\hline $\mathrm{BH} 31$ & No & No & No & No & No & No & No & No \\
\hline BH32 & 4.5 & 7.0 & 3.0 & 161.3 & 178.8 & 144.5 & 204.7 & 115.1 \\
\hline BH32 & 6.0 & 32 & 3.0 & 345.1 & 252.3 & 207.56 & 275.3 & 292.7 \\
\hline BH32 & 9.0 & 40 & 3.0 & 385.8 & 308.9 & 256.8 & 327.6 & 506.1 \\
\hline BH32 & 12 & 54 & 3.0 & 448.3 & 339.5 & 283.5 & 355.3 & 653.1 \\
\hline BH33 & No & No & No & No & No & No & No & No \\
\hline BH34 & 3.0 & 20 & 3.0 & 272.9 & 248.5 & 204.3 & 271.7 & 280.74 \\
\hline BH34 & 4.5 & 21 & 3.0 & 279.6 & 252.3 & 207.56 & 275.3 & 292.7 \\
\hline BH35 & 3.0 & 9 & 2.5 & 183 & 194 & 157 & 219 & 142.5 \\
\hline BH35 & 4.5 & 8 & 2.5 & 172.6 & 186.4 & 150.9 & 212.2 & 128.9 \\
\hline BH35 & 7.5 & 10 & 2.5 & 192.9 & 199.9 & 162.5 & 225.4 & 155.8 \\
\hline BH35 & 12 & 12 & 2.5 & 211.4 & 211.7 & 172.6 & 236.7 & 181.9 \\
\hline BH36 & 3 & 16 & 3.5 & 244 & 232 & 189.8 & 255.8 & 232.3 \\
\hline BH36 & 4.5 & 16 & 3.5 & 244 & 232 & 189.8 & 255.8 & 232.3 \\
\hline BH37 & No & No & No & No & No & No & No & No \\
\hline BH38 & No & No & No & No & No & No & No & No \\
\hline BH39 & No & No & No & No & No & No & No & No \\
\hline BH40 & 3 & 20 & 2.25 & 272.9 & 248.5 & 204.3 & 271.7 & 280.74 \\
\hline BH40 & 4.5 & 49 & 2.25 & 427 & 329.3 & 274.5 & 346.1 & 602 \\
\hline $\mathrm{BH} 40$ & 9 & 16 & 2.25 & 244 & 232 & 189.8 & 255.8 & 232.3 \\
\hline
\end{tabular}




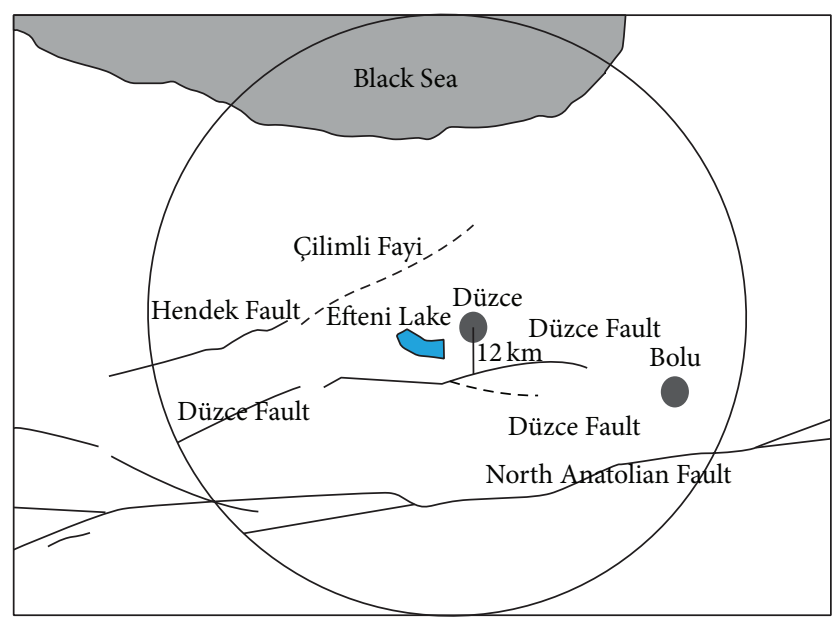

FIGURE 6: Identification of seismic sources within $100 \mathrm{~km}$ radius of the study area.

3.2. Calculation of Seismic Hazard Design Parameters. The Duzce Fault Zone is situated $13 \mathrm{~km}$ south of the study area, the North Anatolian Fault Zone is located $73 \mathrm{~km}$ south of the study area, and the Hendek Fault is found $29 \mathrm{~km}$ north-west of the study field (Figure 6). The fault zone with the highest possible acceleration in the study site is the North Anatolian Fault Zone. A circle with a radius of $100 \mathrm{~km}$ was drawn around the study area in order to identify the seismic design parameters. Within this circle, active seismic sources thought to affect the study field were vertically connected to calculate the shortest routes to the study field in km (Figure 6). These investigations and measurements showed that there were three main fault zones inside the circle. Then, the horizontal flying distances to the study field were calculated as $13 \mathrm{~km}$ for the Duzce Fault, $29 \mathrm{~km}$ for the Hendek Fault, and $73 \mathrm{~km}$ for the North Anatolian Fault [35].

The map of Turkey's active faults published by the Mineral Research and Exploration Institute indicates the total length of the Duzce, Hendek, and North Anatolian Faults as $85 \mathrm{~km}$, $60 \mathrm{~km}$, and $200 \mathrm{~km}$, respectively [35]. The DuzceFault, which is the shortest distance to the study area and has the potential to produce an earthquake, was taken into consideration in the main objective of the study when estimating the next earthquake expected to occur.

According to Mark [39], it is assumed that $1 / 3$ of this fault zone could be ruptured. Therefore, the moment size of the probable seismic design was calculated by using the equation of Wells and Coppersmith [40], as seen below (6):

$$
M=4.86+1.32 \log L
$$

where $M$ is moment magnitude and $L$ is fault length $(\mathrm{km})$.

According to this approach, moment magnitude was calculated to be 7.2 in the case of a rupture of $1 / 3$ of the fault length.

Horizontal earthquake acceleration (peak ground acceleration, PGA) was calculated by using the attenuation relationship (7) developed for faults based on the earthquakes in Turkey [41]:

$$
\mathrm{PGA}=2.18 e^{0,0218\left(33,3 M_{w}-\mathrm{Re}+7.8427 S_{A}+18.9282 S_{B}\right)},
$$

where $S_{A}=0$ and $S_{B}=1$ values are used for soft soils, Re is the shortest horizontal flying length to the respective fault zone from the settlement, and $M_{w}$ is the magnitude of the earthquake. The peak horizontal earthquake acceleration that can be created by the seismic design was found to be $0.28 \mathrm{~g}$.

\section{Assessment of Liquefaction Potential}

Prediction of the liquefaction potential of soils is based on cyclic laboratory testing on soil samples and use of in-situ tests and empirical methods. However, the use of laboratory testing is complicated due to difficulties associated with sample disturbance during both sampling and reconsolidation. Thus, empirical approaches based on the in-situ penetration test results have gained popularity in engineering practice as well as in engineering codes [42].

In this study, after obtaining the in situ test results, the evaluation of the liquefaction procedure was begun. The evaluation procedures based on the Standard Penetration Test (SPT) [43] and measurement of shear wave velocity $\left(V_{S}\right)$ [27] require the measurement of three parameters: (1) the level of cyclic loading on the soil caused by the earthquake, expressed as an acyclic stress ratio (CSR); (2) the stiffness of the soil, expressed as over burden stress (corrected SPT blow count) due to shear wave velocity; and (3) the resistance of the soil to liquefaction, expressed as a cyclic resistance ratio (CRR). Guidelines for calculating each parameter are presented below [44].

4.1. Cyclic Stress Ratio (CSR). The cyclic stress ratio (CSR) characterizes the seismic demand induced by a given earthquake, and it can be determined from peak ground surface acceleration that depends upon site-specific ground motions [45]. The expression for the CSR induced by earthquake ground motions formulated by Idriss and Boulanger [46] is as follows:

$$
\mathrm{CSR}=0.65 \frac{a_{\max }}{g} \frac{\sigma_{V}}{\sigma_{V}^{\prime}} r_{d} \frac{1}{\mathrm{MSF}} \frac{1}{K \sigma},
$$

where 0.65 is a weighing factor to calculate the equivalent uniform stress cycles required to generate the same pore water pressure during an earthquake; the $a_{\max }$ is the peak horizontal ground acceleration; $g$ is the acceleration of gravity; $\sigma_{V}$ and $\sigma_{V}^{\prime}$ are total vertical overburden stress and effective vertical overburden stress, respectively, at a given depth below the ground surface; $r_{d}$ is the depth-dependent stress reduction factor; MSF is the magnitude scaling factor; and $K \sigma$ is the overburden correction factor.

The stress reduction factor $\left(r_{d}\right)$ accounts for the dynamic response of the soil column and represents the variation of shear stress amplitude with depth. Idriss and Boulanger [46] 
formulated the following expressions to calculate the stress reduction factor $\left(r_{d}\right)(9)-(11)$ :

$$
\begin{gathered}
r_{d}=\exp \left[\alpha(z)+\beta(z) M_{w}\right], \\
\alpha(z)=-1.012-1.126 \sin \left(\frac{z}{11.73}+5.133\right), \\
\beta(z)=0.106+0.118 \sin \left(\frac{z}{11.28}+5.142\right),
\end{gathered}
$$

where $z$ is the depth (m) and $M_{w}$ is the moment magnitude. The arguments inside the sine terms in (10) and (11) are in radians. The above expression for $r_{d}$ is valid up to a depth of $z \leq 34 \mathrm{~m}$, and the depths of the boreholes considered in the present analysis were less than $34 \mathrm{~m}$.

The values of CSR that pertain to the equivalent uniform shear stress induced by an earthquake of magnitude, $M_{w}=$ 7.5, were adjusted to an equivalent CSR for an earthquake of magnitude $M_{w}=7.5$ through the introduction of the magnitude scaling factor (MSF), which accounts for the duration effect of ground motions. The MSF for $M_{w}<7.5$ is expressed as follows (12):

$$
\mathrm{MSF}=6.9 \exp \left(-\frac{M_{w}}{4}\right)-0.058 \leq 1.8
$$

Since the liquefaction resistance increases with increasing confining stress, the overburden correction factor $(K \sigma)$ was applied such that the values of CSR were adjusted to an equivalent overburden pressure $\sigma_{V}^{\prime}$ of 1 atmosphere equations (13)-(14):

$$
K \sigma=1-C \sigma\left(\frac{\ln }{\sigma v}\right) \leq 1.0
$$

where

$$
C_{\sigma}=\frac{1}{18.9-2.5507 \sqrt{\left(N_{1}\right)_{60}}} \leq 0.3
$$

$P_{a}$ is the atmospheric pressure $(=00 \mathrm{kPa})$.

4.2. Corrected SPT Blowcount and Shear Wave Velocity. In this study, the measured SPT $N$ values $(N)$ were corrected for overburden stress, energy ratio, diameter of boreholes, length of sampling rod, and the type of sampler by introducing a series of correction factors. $N_{60}$ is the corrected $N_{m}$ value for a $60 \%$ energy ratio with an assumption that $60 \%$ of the energy was transferred from the falling hammer to the SPT sampler. The corrected $\left(N_{1}\right)_{60}$ values were calculated as follows (15):

$$
\left(N_{1}\right)_{60}=N_{m} C_{N} C_{E} C_{B} C_{R} C_{R}
$$

where $C_{N}$ is a factor to normalize $N_{m}$ to a common reference effective overburden stress; $C_{E}$ is the correction for the hammer energy ratio $\left(E_{R}\right) ; C_{B}$ is the correction factor for borehole diameter; $C_{R}$ is the correction factor for rod length; and $C_{S}$ is the correction for samplers with or without liners. The value of $C_{N}$ was calculated as per (15) and was limited to a maximum value of 1.7. $C_{S}, C_{B}$, and $C_{E}$ were assumed to be 1.1,
TABLE 3: The rod length correction with respect to the depth.

\begin{tabular}{lc}
\hline Depth & Correction for rod length \\
$d$ & $C_{R}$ \\
\hline$d<3 \mathrm{~m}$ & 0.75 \\
$d=3-4 \mathrm{~m}$ & 0.8 \\
$d=4-6 \mathrm{~m}$ & 0.85 \\
$d=6-10 \mathrm{~m}$ & 0.95 \\
$d=10-30 \mathrm{~m}$ & $1.0 \mathrm{~m}$ \\
\hline
\end{tabular}

1.0 , and 0.6 , respectively. Rod length correction with respect to the depth $\left(C_{R}\right)$ at each borehole location was corrected as shown in Table 3 , as suggested by Youd and Idriss [47].

The overburden correction $\left(C_{N}\right)$ factor to normalize $\left(N_{1}\right)_{60}$ to a common reference effective overburden stress is as follows (16)-(17):

$$
C_{N}=\left(\frac{P_{a}}{\sigma_{V}^{\prime}}\right)^{\alpha} \leq 1.7,
$$

where

$$
\alpha=0.784-0.0768 \sqrt{ }\left(N_{1}\right)_{60} .
$$

It can be observed from (16) and (17) that $\left(N_{1}\right)_{60}$ and $C_{N}$ are interdependent. A series of iterations were carried out to determine $\left(N_{1}\right)_{60}$ and $C_{N}$ until the difference between successive iteration values was less than 0.001 .

In addition, shear wave velocities had to be corrected. In the procedure of liquefaction potential evaluation proposed by Andrus et al. [27], shear wave velocity was corrected to overburden stress and (18) was suggested:

$$
V_{S 1}=V_{S 1}\left(\frac{P_{a}}{\sigma_{V}^{\prime}}\right)^{0.25}\left(\frac{0.5}{K_{O}^{\prime}}\right)^{0.125}
$$

where $V_{S}$ is the shear wave velocity $(\mathrm{m} / \mathrm{s}) ; V_{S 1}$ is the stresscorrected shear wave velocity $(\mathrm{m} / \mathrm{s}) ; P_{a}$ is the atmosphere pressure equal to $100 \mathrm{kPa} ; \sigma_{V}^{\prime}$ shows the the effective overburden stress; and $K_{O}^{\prime}$ is the coefficient of effective earth pressure (in this study assumed equal to 0.5) [44].

4.3. Evaluation of the Cyclic Resistance Ratio (CRR). Determination of the cyclic resistance ratio (CRR) requires fines content (FC) of the soil to correct updated SPT blow count $\left(N_{1}\right)_{60}$ to an equivalent clean sand standard penetration resistance value $\left(N_{1}\right)_{60 \mathrm{cs}}$. Idriss and Boulanger [46] determined the CRR value for cohesionless soil with any fines content using the following expression (19)-(21):

$$
\begin{gathered}
\mathrm{CRR}=\exp \left\{\frac{\left(N_{1}\right)_{60 \mathrm{cs}}}{14.1}+\left(\frac{\left(N_{1}\right)_{60 \mathrm{cs}}}{126}\right)^{2}-\left(\frac{\left(N_{1}\right)_{60 \mathrm{cs}}}{23.6}\right)^{3}\right. \\
\left.+\left(\frac{\left(N_{1}\right)_{60 \mathrm{cs}}}{25.4}\right)^{3}-\frac{2.8}{1}\right\} \\
\left(N_{1}\right)_{60 \mathrm{cs}}=\left(N_{1}\right)_{60}+\Delta\left(N_{1}\right)_{60}
\end{gathered}
$$




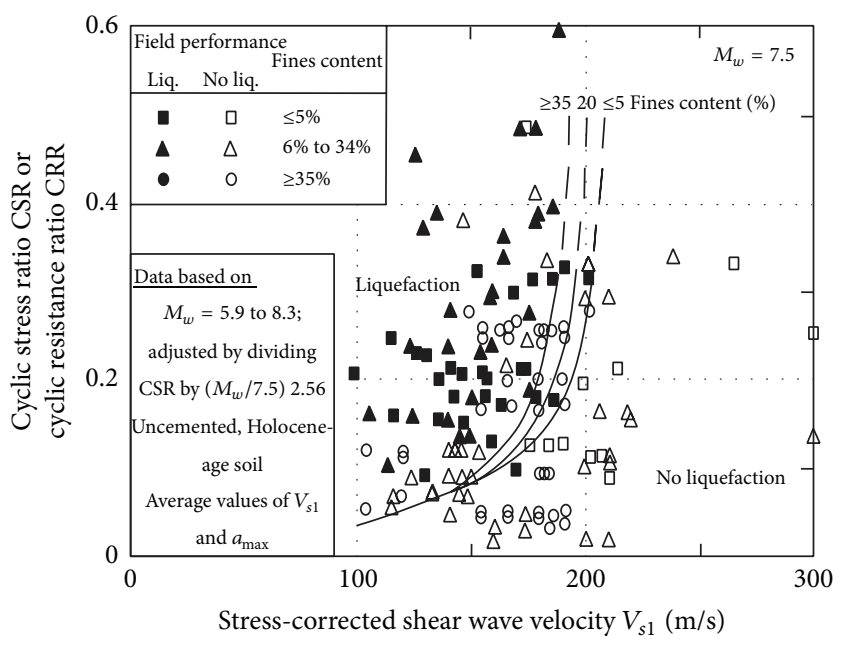

FIgURE 7: Recommended curves for evaluating CRR from shear wave velocity $V_{S}$ for clean, uncemented soils with liquefaction data from compiled case histories [27].

where $\Delta\left(N_{1}\right)_{60}$ is the correction for fines content in percent (FC) present in the soil and is expressed as

$$
\Delta\left(N_{1}\right)_{60}=\exp \left(1.63+\frac{9.7}{\mathrm{FC}+0.1}-\left(\frac{15.7}{\mathrm{FC}+0.1}\right)^{2}\right) .
$$

Separately, as regarding the use of $V_{S}$ as an index of liquefaction resistance, it has been illustrated by several authors. The most popular CRR- $V_{S}$ correlation (Figure 7) was proposed by Andrus and Stokoe [22] for uncemented Holocene-age soils, based on a database including 26 earthquakes and more than 70 test sites. The CRR is obtained as a function of an overburden-stress corrected shear wave velocity $V_{S 1}=$ $V_{S}\left(P_{a} / \sigma_{V 0}^{\prime}\right)^{0.25}$, where $V_{S}=$ measured shear wave velocity, $P_{a}=$ atmospheric pressure $\left(\approx 100 \mathrm{kp}_{a}\right)$, and $\sigma_{V 0}^{\prime}=$ initial effective vertical stress (same units as $P_{a}$ ). Andrus et al. [27] introduced age correction factors to extend the original correlation of Andrus and Stokoe [22] to soils older than Holocene. Their CRR-VS1 relationship (curves in Figure 7, for various fines contents) is approximated by:

$$
\begin{aligned}
\mathrm{CRR}= & {\left[0.022\left(\frac{K_{a 1} V_{S 1}}{100}\right)^{2}+2.8\left(\frac{1}{V_{S 1}^{*}-K_{a 1} V_{s 1}}-\frac{1}{V_{S 1}^{*}}\right)\right] } \\
& \times K_{a 2},
\end{aligned}
$$

where $V_{S 1}^{*}=$ the limiting upper value of $V_{S 1}$ for liquefaction occurrence $\left(V_{S 1}^{*}=200 \mathrm{~m} / \mathrm{s}\right.$ for the curve for fines content $\geq 35 \%) ; V_{S 1}^{*}=215 \mathrm{~m} / \mathrm{s}$ for the curve for fines content $\leq 5 \%$; $V_{S 1}^{*}$ varies linearly from 200 to $215 \mathrm{~m} / \mathrm{s}$ for fines content between 35 and $5 \% ; K_{a 1}=$ factor to correct for high $V_{S 1}$ values caused by aging; and $K_{a 2}=$ Factor to correct for influence of age on CRR. Magnitude scaling factors should be used to scale (22) (for magnitude $M_{w}=7.5$ earthquakes) to different magnitudes. Both $K_{a 1}$ and $K_{a 2}$ are 1 for uncemented soils of Holocene age. For older soils, suggested $K_{a 1}$ values (mostly in
TABLE 4: The level of liquefaction severity.

\begin{tabular}{lccc}
\hline LPI & Iwasaki et al. & Luna and Frost & MERM \\
& {$[23]$} & {$[37]$} & {$[38]$} \\
\hline LPI $=0$ & Very low & Little to none & None \\
$0<$ LPI $<5$ & Low & Minor & Low \\
$5<$ LPI $<15$ & High & Moderate & Medium \\
$15<$ LPI & Very high & Major & High \\
\hline
\end{tabular}

the range 0.6 to 0.8 ) are derived from SPT- $V_{S 1}$ relationships (e.g. Ohta and Goto [48], Rollins et al. [49], or site specific). Lower-bound values of $K_{a 2}$ (1.1 to 1.5) are based on the study by Arango et al. [50]. However, Andrus et al. [27] noted the associated high uncertainty and the need for additional work to quantify the influence of age on CRR, as well as on $V_{s}$.

4.3.1. Determination of the Factor of Safety. The factor of safety against liquefaction (FS) is commonly used to quantify liquefaction potential. The factor of safety against liquefaction (FS) can be defined as follows:

$$
\mathrm{FS}=\frac{(\mathrm{CRR})_{M_{w}=7.5}}{(\mathrm{CSR})_{M_{w}=7.5, \sigma_{V}^{\prime}}} \mathrm{MSF} .
$$

Both CSR and CRR vary with depth and, therefore, the liquefaction potential is evaluated at corresponding depths within the soil profile.

4.3.2. Determination of the Liquefaction Potential Index. The liquefaction potential index (LPI) is a single-valued parameter to evaluate regional liquefaction potential. The LPI at a site is computed by integrating the factors of safety (FS) along the soil column up to a depth of $20 \mathrm{~m}$. A weighting function is added to give more weight to the layers closer to the ground surface. The liquefaction potential index (LPI) proposed by Iwasaki et al. [36, 51] is expressed as follows $(24)$. The criteria of the level of liquefaction severity indexes were given below (Table 4):

$$
\text { LPI }=\int_{0}^{20} F_{(z)} W_{(z)} d_{z},
$$

where $z$ is the depth of the midpoint of the soil layer $(0$ to $20 \mathrm{~m})$ and $d_{z}$ is the differential increment of depth. The weighting factor, $W(z)$, and the severity factor, $F(z)$, are calculated as per the following expressions (25):

$$
\begin{aligned}
F(z) & =1-\mathrm{FS} \quad \text { for } \mathrm{FS}<1.0, \\
F(z) & =0 \text { for } \mathrm{FS} \geq 1.0, \\
W(z) & =10-0.5 z \text { for } z<20 \mathrm{~m}, \\
W(z) & =0 \text { for } z>20 \mathrm{~m} .
\end{aligned}
$$

For the soil profiles with depths of less than $20 \mathrm{~m}$. The LPI was calculated using the following expression [37] (26)-(27):

$$
\text { LPI }=\sum_{i=1}^{n} W_{i} F_{i} H_{i}
$$



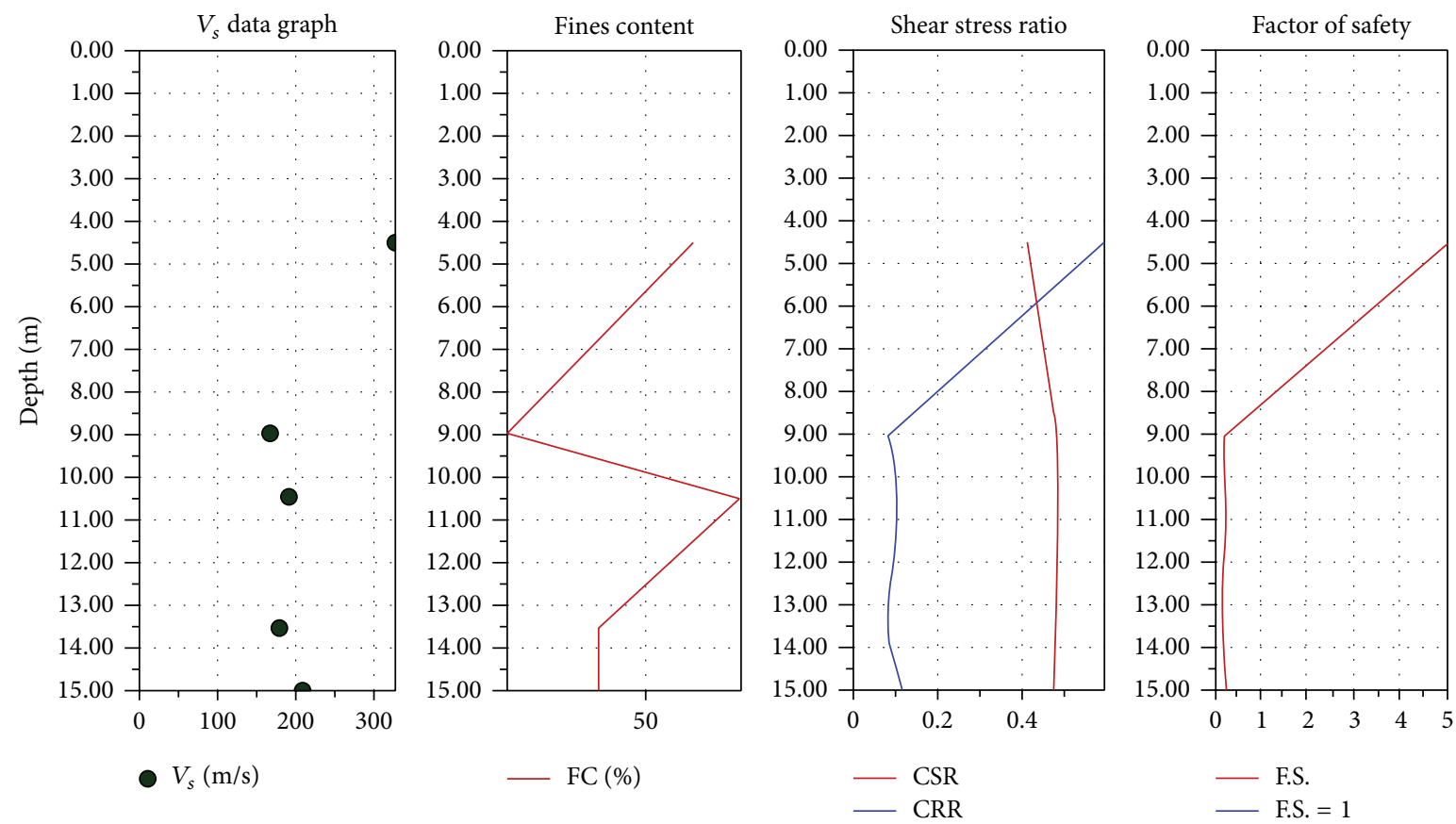

FIGURE 8: Borehole 23 was chosen to check and compare for liquefaction potential as a sample according to shear wave velocity values.

with

$$
\begin{gathered}
F_{i}=1-\mathrm{FS}_{i} \text { for } \mathrm{FS}_{i}<1.0, \\
F_{i}=0 \text { for } \mathrm{FS}_{i} \geq 1.0,
\end{gathered}
$$

where $H_{i}$ is the thickness of the discretized soil layers; $n$ is the number of layers; $F_{i}$ is liquefaction severity for $i$ th layer; $\mathrm{FS}_{i}$ is the factor of safety for $i$ th layer; $W_{i}$ is the the weighting factor $\left(=10-0.5 Z_{i}\right)$; and $Z_{i}$ is the depth of $i$ th layer $(\mathrm{m})$.

\section{Assessment of the Liquefaction Potential Index}

The city of Duzce has been reconstructed since the 12 November earthquake of 1999. The general form of construction had typically been a 4-5-storey reinforced-concrete frame and masonry structure. After the 12 November Duzce earthquake experience, regulations were changed to limit construction to 2-3-storey buildings. The city is located over deep alluvial deposits. The main soils deposited at this site are comprised of alluvial sand and silt. The boreholes in Duzce were drilled around the Efteni Lake at a depth of $200 \mathrm{~m}$ and did not reach bedrock. The shallow soils at approximately $10 \mathrm{~m}$ are recent deposits laid down by the Aksu and Melen Rivers that flooded the area.

Turkey is located in the active tectonic region of the Alp Himalayan Earthquake Zone, so this area is an active region seismologically. There are several active tectonic sections in Turkey, such as the North Anatolian Fault Zone, the East Anatolian Fault Zone, the West Anatolian Grabens, the Ecemiş Fault Zone, and the Tuzgolu Fault Zone [52]. Duzce Province is located near the Duzce Fault segment of the North Anatolian Fault Zone which is active in the Western Black Sea

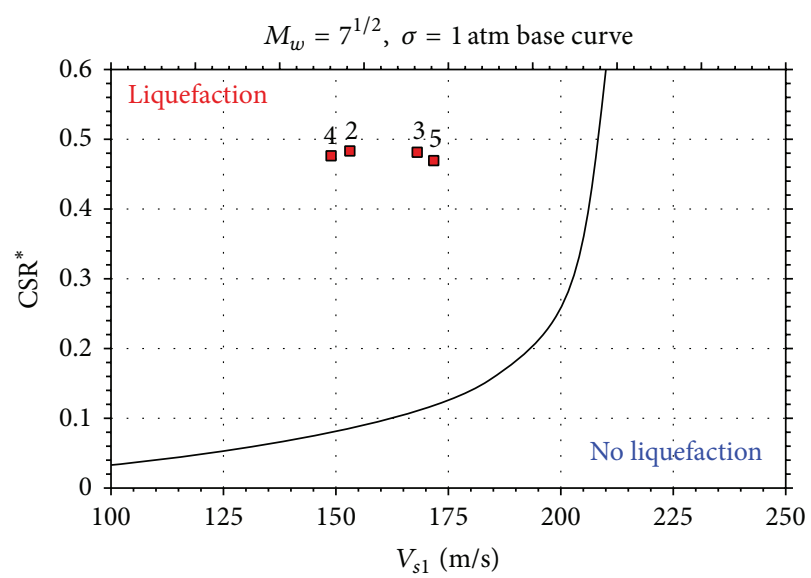

FIgURE 9: Borehole 23 was chosen to check and compare for liquefaction potential as a sample for shear wave velocity.

Region. Furthermore, this area consists of granular alluvial deposits which are loose to the surface. The groundwater is between 2.5 and $4 \mathrm{~m}$ below the surface and changes seasonally. For the analysis of the liquefaction potential index of Duzce Province, a total of 40 geotechnical boreholes were drilled by the General Directorate of Mineral Research and Exploration. The field data of the works were assessed for the liquefaction potential index for Duzce Province. The SPT samples were implemented at depth intervals of $1.5 \mathrm{~m}$ from the first to the last of the boreholes, and the disturbed samples were used to describe the grain size distribution and Atterberg limits of the soils. The boundaries of the soil layers, SPT- $N$ values, fines content, and the liquid limit for all layers 

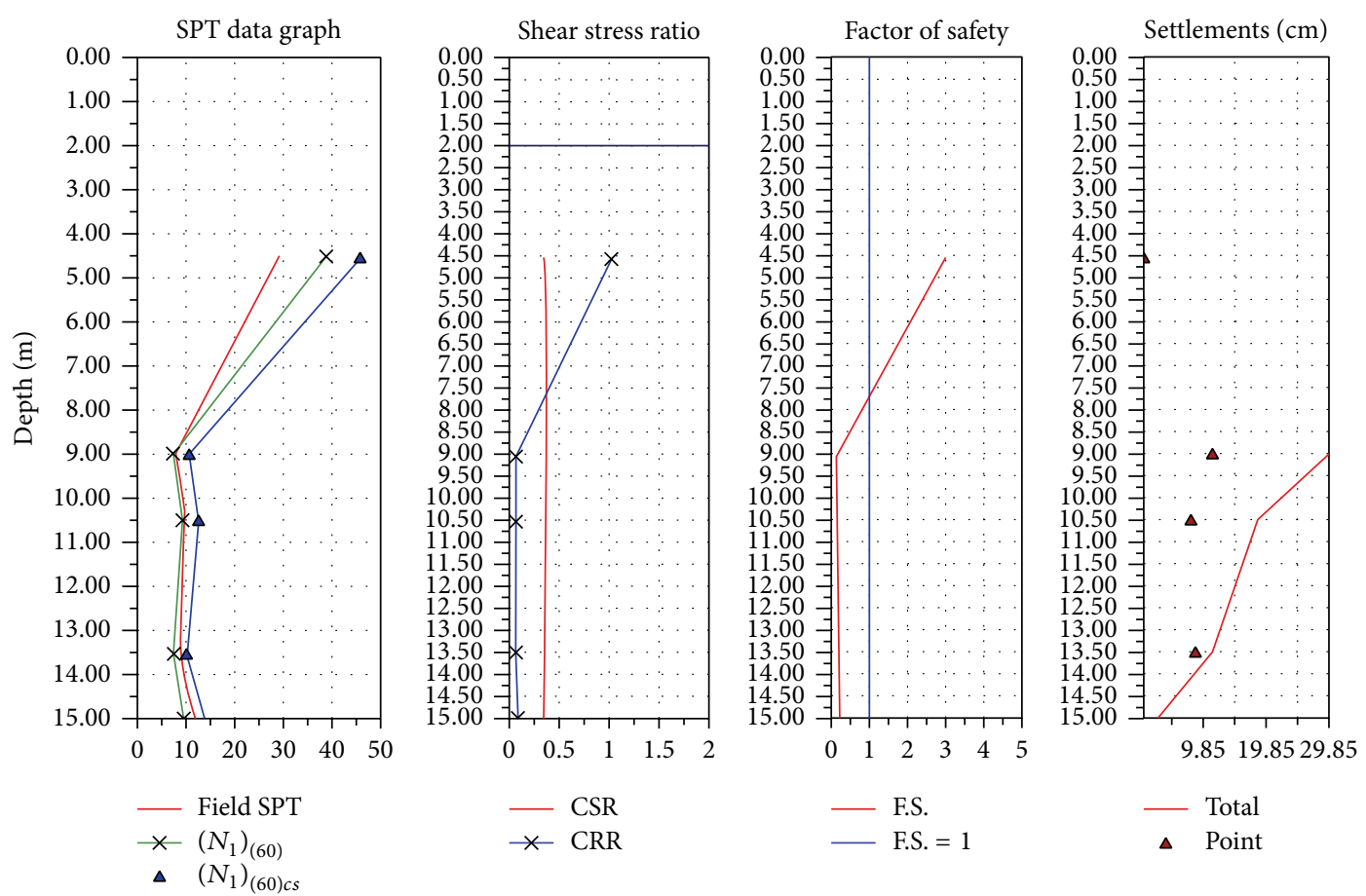

FIGURE 10: Borehole 23 was chosen to check and compare for liquefaction potential as a sample according to the SPT- $N$ values.

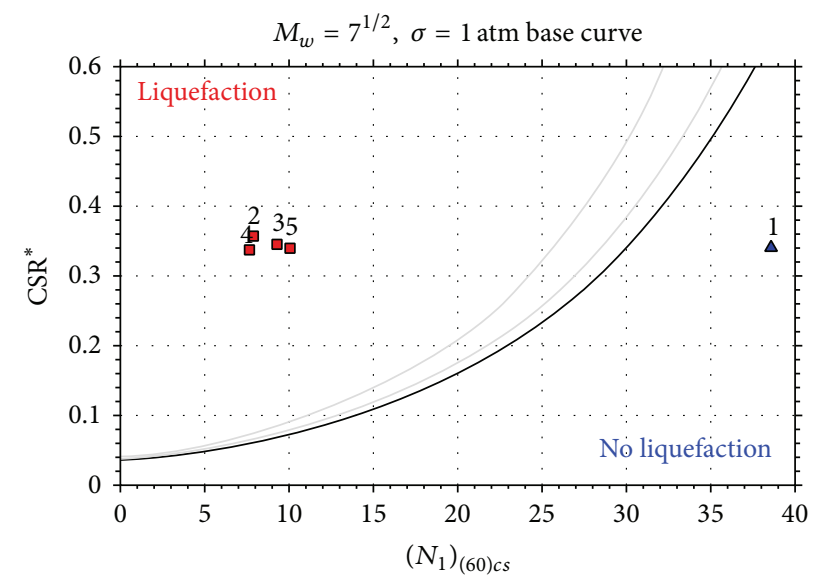

FIGURE 11: Borehole 23 was chosen to check and compare for liquefaction potential as scattering liquefaction points of sample for SPT- $N$ values.

throughout the boreholes were employed as input parameters to determine the liquefaction potential index.

In addition, the magnitude of the earthquake and the maximum horizontal acceleration of those parameters to be created due to local faults were used here for evaluating the liquefaction potential index. The Duzce Fault Zone of the North Anatolian Fault Zone and surrounding zones were generated and showed an average of 7.2 moment magnitudes. For this reason, the magnitude of the projected earthquake was found by using 7.2 for the calculations. In this context, the typical computation of factors of safety against liquefaction for earthquakes $\left(M_{w}=7.2\right)$ yielded by the Duzce Fault Zone was carried out at the chosen borehole using (2) through (20). The LPI at this particular site was calculated from the FS values based on the expression by Luna and Frost [37]. The LPI values were computed at the study site for magnitudes of $M_{w}=7.2$.

Great effort was taken in the analysis of the other input parameter for determining the liquefaction potential, the maximum ground acceleration $\left(a_{\max }\right)$. However, some researchers have offered empirical equations for the maximum ground acceleration [41, 53, 54]. In particular, the comprehensive study of Ulusay et al. [41] should be mentioned as it relates to the iso-acceleration map of Turkey. In this study, the $a_{\max }$ values were calculated as approximately 502 gal for the Duzce Fault Zone segment. The liquefaction potential index indices for 40 boreholes were calculated and are given in Table 5 and Figures 8, 9, 10, and 11. In addition, 
TABLE 5: Liquefaction potential index results.

\begin{tabular}{|c|c|c|c|c|c|}
\hline \multirow{2}{*}{ Boreholes number } & \multicolumn{5}{|c|}{ The level of liquefaction severity (LPI) } \\
\hline & Equation (1) & Equation (2) & Equation (3) & Equation (4) & Equation (5) \\
\hline $\mathrm{BH} 1$ & 0 & 0 & 0 & 0 & 0 \\
\hline $\mathrm{BH} 2$ & 0 & 0 & 14.14 & 19.79 & 0 \\
\hline BH3 & 0 & 0 & 35.63 & 0 & 0 \\
\hline $\mathrm{BH} 4$ & 30.32 & 13.35 & 39.17 & 0 & 28.97 \\
\hline BH5 & Not performed & 0 & Not performed & Not performed & Not performed \\
\hline BH6 & 0 & 0 & 23.09 & 0 & 0 \\
\hline $\mathrm{BH} 7$ & Not performed & Not performed & Not performed & Not performed & Not performed \\
\hline BH8 & 46.83 & 33.46 & 26.34 & 5.82 & 40.87 \\
\hline BH9 & 0 & 0 & 0 & 0 & 0 \\
\hline BH10 & Not performed & Not performed & Not performed & Not performed & Not performed \\
\hline BH11 & 5.43 & 0 & 0.8 & 0 & 24.39 \\
\hline BH12 & 0 & 0 & 0 & 0 & 0 \\
\hline $\mathrm{BH} 13$ & Not performed & Not performed & Not performed & Not performed & Not performed \\
\hline $\mathrm{BH} 14$ & 0 & 9.14 & 0 & 0 & 0 \\
\hline BH15 & Not performed & Not performed & Not performed & Not performed & Not performed \\
\hline BH16 & 0 & 0 & 0 & 0 & 0 \\
\hline BH17 & 10.5 & 5.37 & 0 & 0 & 8.90 \\
\hline BH18 & 0 & 0 & 0 & 0 & 0 \\
\hline BH19 & 0 & 0 & 24.17 & 0 & 0 \\
\hline $\mathrm{BH} 20$ & Not performed & Not performed & Not performed & Not performed & Not performed \\
\hline $\mathrm{BH} 21$ & Not performed & Not performed & Not performed & Not performed & Not performed \\
\hline $\mathrm{BH} 22$ & Not performed & Not performed & Not performed & Not performed & Not performed \\
\hline $\mathrm{BH} 23$ & 23.86 & 36.96 & 35.26 & 42.53 & 40.84 \\
\hline $\mathrm{BH} 24$ & 1.5 & 0 & 19.89 & 35.34 & 26.39 \\
\hline $\mathrm{BH} 25$ & 17.85 & 14.52 & 14.68 & 8.48 & 19.94 \\
\hline BH26 & 5.68 & 0 & 41.81 & 0 & 22.44 \\
\hline $\mathrm{BH} 27$ & Not performed & Not performed & Not performed & Not performed & Not performed \\
\hline $\mathrm{BH} 28$ & Not performed & Not performed & Not performed & Not performed & Not performed \\
\hline $\mathrm{BH} 29$ & 0 & 8 & 9.51 & 0 & 0 \\
\hline $\mathrm{BH} 30$ & Not performed & Not performed & Not performed & Not performed & Not performed \\
\hline BH31 & Not performed & Not performed & Not performed & Not performed & Not performed \\
\hline BH32 & 33.05 & 22.94 & 32.74 & 0 & 30.74 \\
\hline $\mathrm{BH} 33$ & Not performed & Not performed & Not performed & Not performed & Not performed \\
\hline $\mathrm{BH} 34$ & 0 & 0 & 0 & 0 & 0 \\
\hline BH35 & 66.53 & 31.64 & 56.95 & 2.84 & 59.78 \\
\hline BH36 & 0 & 0 & 9.67 & 0 & 0 \\
\hline BH37 & Not performed & Not performed & Not performed & Not performed & Not performed \\
\hline $\mathrm{BH} 38$ & Not performed & Not performed & Not performed & Not performed & Not performed \\
\hline BH39 & Not performed & Not performed & Not performed & Not performed & Not performed \\
\hline $\mathrm{BH} 40$ & 0 & 0 & 18.88 & 0 & 0 \\
\hline
\end{tabular}




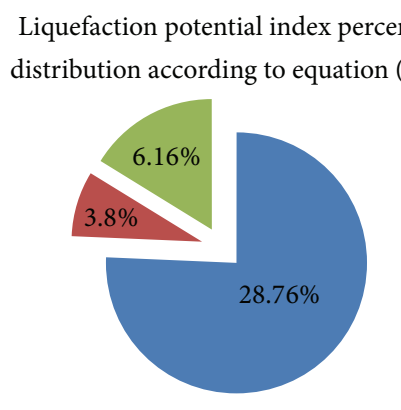

(a)

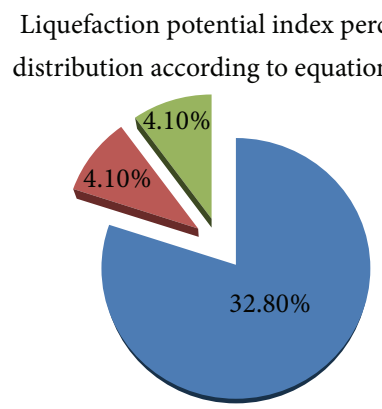

(b)
Liquefaction potential index percent

distribution according to equation (3)

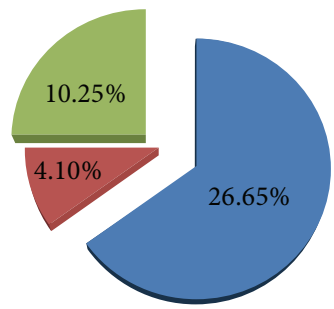

(c)

Liquefaction potential index percent Liquefaction potential index percent

distribution according to equation (4) distribution according to equation (5)

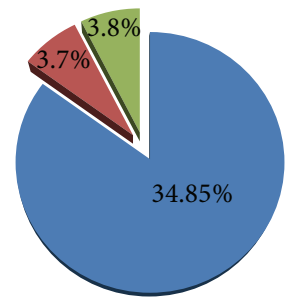

(d)

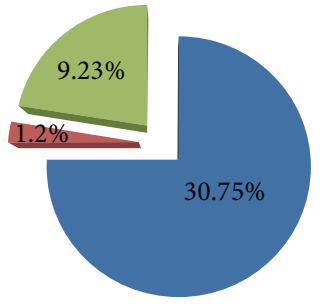

- Low Very high

(e)

FIgURE 12: Pie charts showing the areas of the potential zones.

the distributions of liquefaction potential indexes are presented in Figure 12 as a pie chart.

\section{Results and Conclusions}

The evaluation of the liquefaction potential of a liquefactionprone area is of vital importance in geotechnical earthquake engineering, both for assessment for site selection and for planning and construction. This study investigated two field methods used to evaluate the liquefaction potential of soils, the Standard Penetration Test (SPT) and the Shear Wave Velocity Test $\left(V_{S}\right)$, based on the empirical relationships between them. Attempts were made to evaluate the factors of safety against liquefaction (FS) and corresponding liquefaction potential indices (LPI) for a local fault zone in order to produce the seismic movement for the province using SPT$N$-based semiempirical procedures.

The concept of the liquefaction potential index was used in this study for liquefaction susceptibility, as proposed by Iwasaki et al. [36]. The distribution of the LPI was generated in order to predict the occurrence of damaging liquefaction for an earthquake to be yielded by the local fault zone in Duzce Province in the Western Black Sea Region of Turkey. This study area is under the effect of the North Anatolian Fault Zone through its segment, the Duzce Fault Zone, which was evaluated for producing the liquefaction potential indices by calculating for a probable earthquake of $M_{w}=7.2$.

The comparison of the safety factors and liquefaction potential indexes reveal that the severity of liquefaction occurrences in the study area based on the $V_{S}$ methods (Equation $(1)=43.86$, equation $(2)=40.84$, equation $(3)=$ 42.53 , equation $(4)=36.96$, equation $(5)=43.86)$ are bigger than the one based on the SPT method $(35,36)$. Moreover, it can be observed that the relationships between the SPT method and the shear wave velocity are not suitable. Because the relationships used in the present study are dependent on soil type, fines content, type of tests, and their accuracy, it might be more valid to perform both methods for the same place and then compare the results in order to evaluate the liquefaction potential.

Finally, a very high susceptibility category of liquefaction was observed for the potential earthquake of $M_{w}=7.2$; however, $3.8-10.2 \%$ of the study area is in the highly susceptible liquefaction class in five distribution charts according to (1)-(5). The percentage that is moderately susceptible takes up the least area from the other class: $1.2-4.1 \%$ for all locations in the distribution charts. The low susceptibility areas are $28.76-65 \%$, respectively.

In conclusion, the areas developed on reclaimed land having large, thick deposits of soft soil and shallow groundwater levels were observed to be more prone to liquefaction. This paper reveals that some of the areas are more highly prone to liquefaction due to the greater thickness of the soft soil deposits and groundwater table at shallow depths. It can be observed from the distribution of the LPI that a high degree of liquefaction would occur at several sites in the Province of Duzce during a seismic event. These LPI distributions will 
help the structural designers and city planners to check the vulnerability of the area against liquefaction.

\section{Conflict of Interests}

The authors declare that there is no conflict of interests regarding the publication of this paper.

\section{Acknowledgments}

The authors would like to express their gratitude to the Duzce Provincial Governorate and the General Directorate of Mineral Research and Exploration for information and the logs of geotechnical boreholes.

\section{References}

[1] H. B. Seed and I. M. Idriss, "Simplified procedure for evaluating soil liquefaction potential," Journal of the Soil Mechanics and Foundations Division, vol. 97, no. 9, pp. 1249-1273, 1971.

[2] T. L. Youd, I. M. Idriss, R. D. Andrus et al., "Liquefaction resistance of soils: summary report from the 1996 NCEER and 1998 NCEER/NSF workshops on evaluation of liquefaction resistance of soils," Journal of Geotechnical and Geoenvironmental Engineering, vol. 127, no. 10, pp. 817-833, 2001.

[3] H. B. Seed, I. M. Idris, and I. Arango, "Evaluation of liquefaction potential using field performance data," Journal of Geotechnical Engineering, vol. 109, no. 3, pp. 458-482, 1983.

[4] H. B. Seed, K. Tokimatsu, L. F. Harder, and R. M. Chung, "The influence of SPT procedures in soil liquefaction resistance evaluation," Journal of Geotechnical Engineering, vol. 111, no. 12, pp. 1425-1445, 1985.

[5] B. O. Hardin and V. P. Drnevich, "Shear modulus and damping in soils: design equation and curves," Journal of Soil Mechanics and Foundation, vol. 98, no. 7, pp. 667-692, 1972.

[6] S. Kramer, Geotechnical Earthquake Engineering, Prentice Hall, Upper Saddle River, NJ, USA, 1996.

[7] K. Ishihara, Soil Behaviour in Earthquake Geotechnics, Oxford Engineering Science Series, Oxford University Press, Oxford, UK, 1996.

[8] A. F. Rauch, M. Duffy, and K. H. Stokoe II, "Laboratory correlation of liquefaction resistance with shear wave velocity," in Proceedings of the Sessions of Computer Simulation of Earthquake Effects (Geo-Denver '00), vol.110, pp. 66-80, Denver, Colo, USA, August 2000.

[9] Y.-T. Huang, A.-B. Huang, Y.-C. Kuo, and M.-D. Tsai, "A laboratory study on the undrained strength of a silty sand from Central Western Taiwan," Soil Dynamics and Earthquake Engineering, vol. 24, no. 9-10, pp. 733-743, 2004.

[10] C. Yunmin, K. Han, and C. Ren-Peng, "Correlation of shear wave velocity with liquefaction resistance based on laboratory tests," Soil Dynamics and Earthquake Engineering, vol. 25, no. 6, pp. 461-469, 2005.

[11] Y.-G. Zhou, Y.-M. Chen, and B. Huang, "Experimental study of seismic cyclic loading effects on small strain shear modulus of saturated sands," Journal of Zhejiang University: Science, vol. 6, no. 3, pp. 229-236, 2005.

[12] N. Liu, J. K. Mitchell, and M. Hon, "Influence of nonplastic fines on shear wave velocity-based assessment of liquefaction," Journal of Geotechnical and Geoenvironmental Engineering, vol. 132, no. 8, pp. 1091-1097, 2006.
[13] Y.-G. Zhou and Y.-M. Chen, "Laboratory investigation on assessing liquefaction resistance of sandy soils by shear wave velocity," Journal of Geotechnical and Geoenvironmental Engineering, vol. 133, no. 8, pp. 959-972, 2007.

[14] C. D. P. Baxter, A. S. Bradshaw, R. A. Green, and J.-H. Wang, "Correlation between cyclic resistance and shear-wave velocity for providence silts," Journal of Geotechnical and Geoenvironmental Engineering, vol. 134, no. 1, pp. 37-46, 2008.

[15] F. Askari, R. Dabiri, A. Shafiee, and M. K. Jafari, "Liquefaction resistance of sand-silt mixtures using laboratory-based shear wave velocity," International Journal of Civil Engineering, vol. 9, no. 2, pp. 135-144, 2011.

[16] R. D. Andrus, In-situ characterization of gravelly soils that liquefied in the 1983 Borah Peak earthquake [Ph.D. thesis], University Of Texas, Austin, Tex, USA, 1994.

[17] R. Dabiri, F. Askari, A. Shafiee, and M. K. Jafari, "Shear wave velocity-based liquefaction resistance of sand-silt mixtures: deterministic versus probabilistic approach," Iranian Journal of Science and Technology-Transaction of Civil Engineering, vol. 35, no. 2, pp. 199-215, 2011.

[18] A. L. Lodge, Shear wave velocity measurements for subsurface characterization [Ph.D. thesis], University of California, Berkeley, Calif, USA, 1996.

[19] K. Kayabali, "Soil liquefaction evaluation using shear wave velocity," Engineering Geology, vol. 44, no. 1-4, pp. 121-127, 1996.

[20] R. D. Andrus and K. H. Stokoe, "Liquefaction resistance based on shear wave velocity," in Proceedings of the NCEER Workshop on Evaluation of Liquefaction Resistance of Soils, T. L. Youd and I. M. Idriss, Eds., Technical Report NCEER-97-0022, pp. 89-128, National Center for Earthquake Engineering Research, Buffalo, NY, USA, Salt lake City, Utah, USA, January 19971996.

[21] C. H. Juang, C. J. Chen, W. H. Tang, and D. V. Rosowsky, “CPTbased liquefaction analysis, part 1: determination of limit state function," Geotechnique, vol. 50, no. 5, pp. 583-592, 2000.

[22] R. D. Andrus and K. H. Stokoe II, "Liquefaction resistance of soils from shear-wave velocity," Journal of Geotechnical and Geoenvironmental Engineering, vol. 126, no. 11, pp. 1015-1025, 2000.

[23] T. Iwasaki, K. Tokida, F. Tatsuoka, S. Watanabe, S. Yasuda, and H. Sato, "Microzonation for soil liquefaction potential using simplified methods," in Proceedings of the 3rd International Conference on Microzonation, pp. 1319-1330, Seattle, Wash, USA, June-July 1982.

[24] NEMC, B.U. Kandıllı Observatory and Earthquake Research Institute, National Earthquake Monitoring Centre, 2014, http:// www.koeri.boun.edu.tr/sismo.

[25] Tubitak-AU-MTA, Investigation of Alternative Settlement Area after 17 August 1999 Earthquake in Duzce District (Bolu), Ankara, Turkey, 1999.

[26] O. Emre, T. Y. Duman, and A. Doğan, The Preassessment Report and Map of Surface Rapture in 17 August 1999 Eastern Marmara Earthquake, No. 22, General Directorate of Mineral Research and Exploration, Ankara, Turkey, 1999.

[27] R. D. Andrus, P. Piratheepan, B. S. Ellis, J. Zhang, and C. H. Juang, "Comparing liquefaction evaluation methods using penetration $\mathrm{V}_{S}$ relationships," Soil Dynamics and Earthquake Engineering, vol. 24, no. 9-10, pp. 713-721, 2004.

[28] E. Gokten, V. Ozaksoy, and R. Demirtas, "Some neotectonical properties of the North Anatolian fault zone between bayramoren-abant (Turkey)," in Active Tectonic Research Group First Meeting Proceeding, pp. 68-77, ITU Mining Faculty-Eurasia Earth Sciences Institute, 1998. 
[29] R. Demirtas, Kuzey anadolu fay zonu'nun abant-gerede arasinda kalan bölümünün neotektonik Özellikleri ve paleosis-misitesi [Ph.D. thesis], University of Ankara, Ankara, Turkey, 2000.

[30] N. N. Ambraseys, "Engineering seismology," Earthquake Engineering \& Structural Dynamics, vol. 17, no. 1, pp. 1-105, 1988.

[31] C. Tasman, "The Report About The Gerede-Bolu Earthquake," DAD/At. 46, 1944 (Turkish).

[32] T. Ugras, Z. Colakoglu, U. Ceken et al., "17 Agustos_Izmit Korfezi Depremi Kuvvetli Yer Hareketi Kayıtlarının Değerlendirilmesi," 17 Ağustos_Izmit Korfezi Deprem Raporu, Bayındırlık Ve Iskan Bakanlığı, Afet Isleri Genel Müdürlügü, Deprem Araştırma Dairesi, Ankara, Pp 156-189, 2000, (Turkish).

[33] American Society for Testingmaterials, "Standard test for penetration test and split-barrel sampling of soils (ASTM D1596)," in Annual Book of ASTM Standards, vol. 04. 09, Section 4, p. 1092, 1994.

[34] M. K. Jafari, A. Shafiee, and A. Razmkhah, "Dynamic properties of fine grained soils in south of tehran," Journal of Seismology and Earthquake Engineering, vol. 4, no. 1, pp. 25-36, 2002.

[35] F. Şaroğlu, O. Emre, and I. Kuşçu, Türkiye Diri Fay Haritası, MTA Genel Müdürlüğü, Ankara, Turkey, 1992.

[36] T. Iwasaki, K. Tokida, F. Tatsuko, and S. Yasuda, "A practical method for assessing soil liquefaction potential based on case studies at various sites in Japan," in Proceedings of the 2nd International Conference on Microzonation, pp. 885-896, San Francisco, Calif, USA, November-December 1978.

[37] R. Luna and J. D. Frost, "Spatial liquefaction analysis system," Journal of Computing in Civil Engineering, vol. 12, no. 1, pp. 4856, 1998.

[38] Microzonation for Earthquake Risk Mitigation (MERM), Microzonation Manual, World Institute for Disaster Risk Management, 2003.

[39] R. K. Mark, "Application of linear statistical model of earthquake magnitude versus fault length in estimating maximum expectable earthquakes," Geology, vol. 5, no. 8, pp. 464-466, 1977.

[40] D. L. Wells and K. J. Coppersmith, "New empirical relationships among magnitude, rupture length, rupture width, rupture area, and surface displacement," Bulletin of the Seismological Society of America, vol. 84, no. 4, pp. 974-1002, 1994.

[41] R. Ulusay, E. Tuncay, H. Sonmez, and C. Gokceoglu, "An attenuation relationship based on Turkish strong motion data and iso-acceleration map of Turkey," Engineering Geology, vol. 74, no. 3-4, pp. 265-291, 2004.

[42] A. Ansal and G. Tonuk, "Source and site effects for microzonation," in Earthquake Geotechnical Engineering: 4th International Conference on Earthquake Geotechnical Engineering-Invited Lectures, K. Pitilakis, Ed., Geotechnical Geological and Earthquake Engineering, Chapter 4, pp. 73-92, Geotechnical Geological and Earthquake Engineering, 2007.

[43] H. B. Seed, K. Tokimatsu, L. F. Harder, and R. M. Chung, "The influence of SPT procedures in soil liquefaction resistance evaluations," Journal of Geotechnical Engineering, vol. 111, no. 12, pp. 1425-1445, 1985.

[44] M. K. Noutash, R. Dabiri, and M. H. Bonab, "The evaluation of soil liquefaction potential using shear wave velocity based on empirical relationships," International Journal of Engineering, vol. 6, no. 4, 2012.

[45] J. Dixit, D. M. Dewaikar, and R. S. Jangid, "Assessment of liquefaction potential index for Mumbai city," Natural Hazards and Earth System Science, vol. 12, no. 9, pp. 2759-2768, 2012.
[46] I. M. Idriss and R. W. Boulanger, "Semi-empirical procedures for evaluating liquefaction potential during earthquakes," Soil Dynamics and Earthquake Engineering, vol. 26, no. 2-4, pp. 115130, 2006.

[47] T. L. Youd and I. M. Idriss, "Liquefaction resistance of soils: summary report from the 1996 NCEER and 1998 NCEER/NSF workshops on evaluation of liquefaction resistance of soils," Journal of Geotechnical and Geoenvironmental Engineering, vol. 127, no. 4, pp. 297-313, 2001.

[48] Y. Ohta and N. Goto, "Empirical shear wave velocity equations in terms of characteristic soil indexes," Earthquake Engineering and Structural Dynamics, vol. 6, no. 2, pp. 167-187, 1978.

[49] K. M. Rollins, N. B. Diehl, and T. J. Weaver, "Implications of VSBPT (N1)60 correlations for liquefaction assessment in gravels," in Geotechnical Earthquake Engineering and Soil Dynamics III, vol. 1 of Geotechnical Special Publication No. 75, pp. 506-517, ASCE, 1998.

[50] I. Arango, M. R. Lewis, and C. Kramer, "Updated liquefaction potential analysis eliminates foundation retrofitting of two critical structures," Soil Dynamics and Earthquake Engineering, vol. 20, no. 1-4, pp. 17-25, 2000.

[51] T. Iwasaki, K. Tokida, F. Tatsuoka, S. Watanabe, S. Yasuda, and H. Sato, "Microzonation for soil liquefaction potential using simplified methods," in Proceedings of the 2nd International Conference on Microzonation, pp. 1319-1330, Seattle, Wash, USA, 1982.

[52] A. Yalcin, C. Gokceoglu, and H. Sönmez, "Liquefaction severity map for Aksaray city center (Central Anatolia, Turkey)," Natural Hazards and Earth System Science, vol. 8, no. 4, pp. 641-649, 2008.

[53] W. B. Joyner and D. M. Boore, "Peak horizontal acceleration and velocity from strong-motion records from the 1997 imperial valley, California earthquake," Bulletin of the Seismological Society of America, vol. 71, no. 6, pp. 2011-2038, 1981.

[54] O. Aydan, M. Sezai, and T. Yarar, "The seismic characteristics of Turkish earthquakes," in Proceedings of the 11th International Conference on Earthquake Engineering, pp. 1-8, Acapulco, Mexico, 1986. 

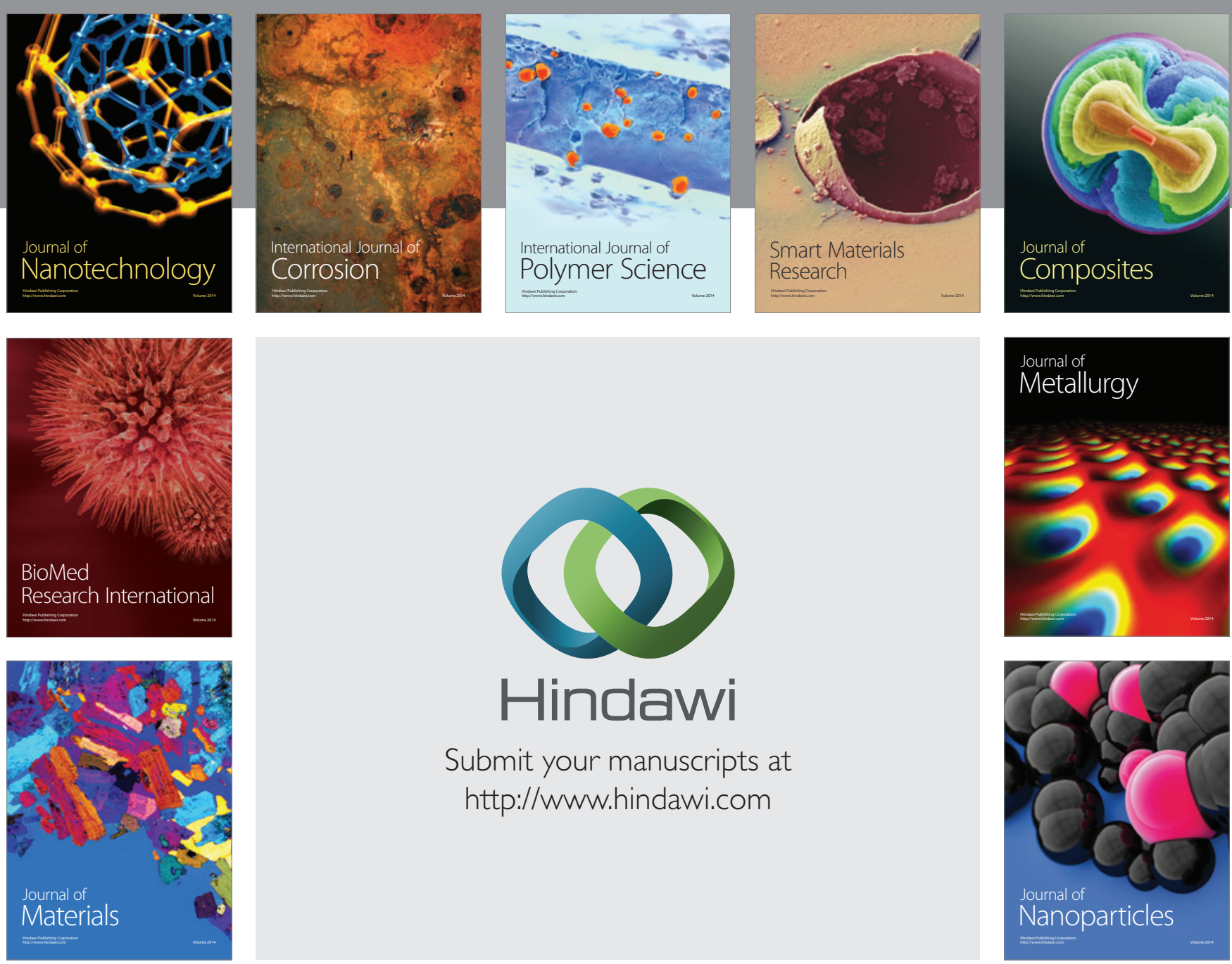

Submit your manuscripts at http://www.hindawi.com
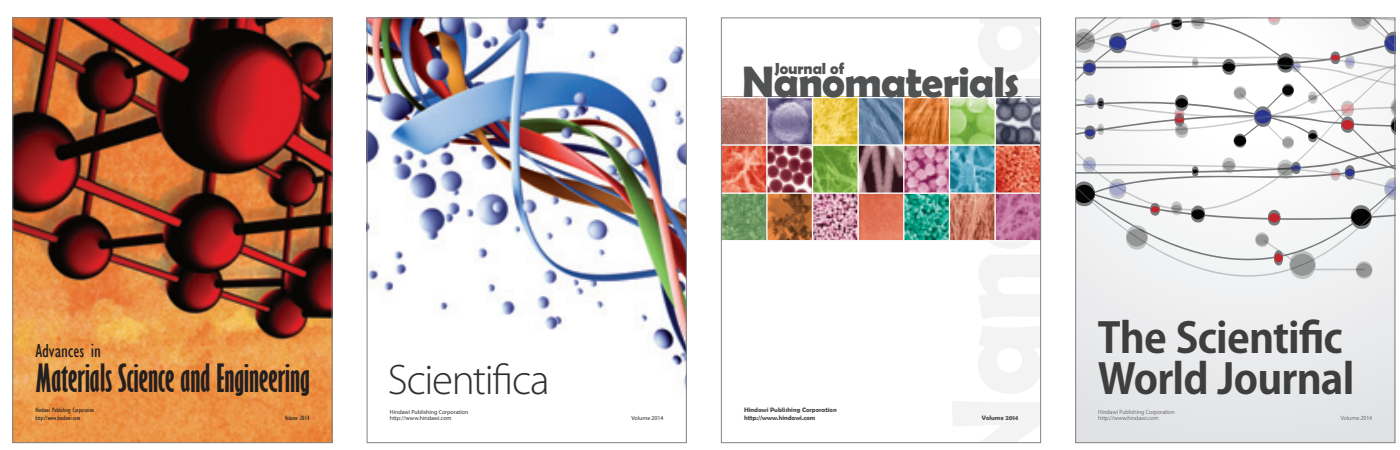

\section{The Scientific World Journal}
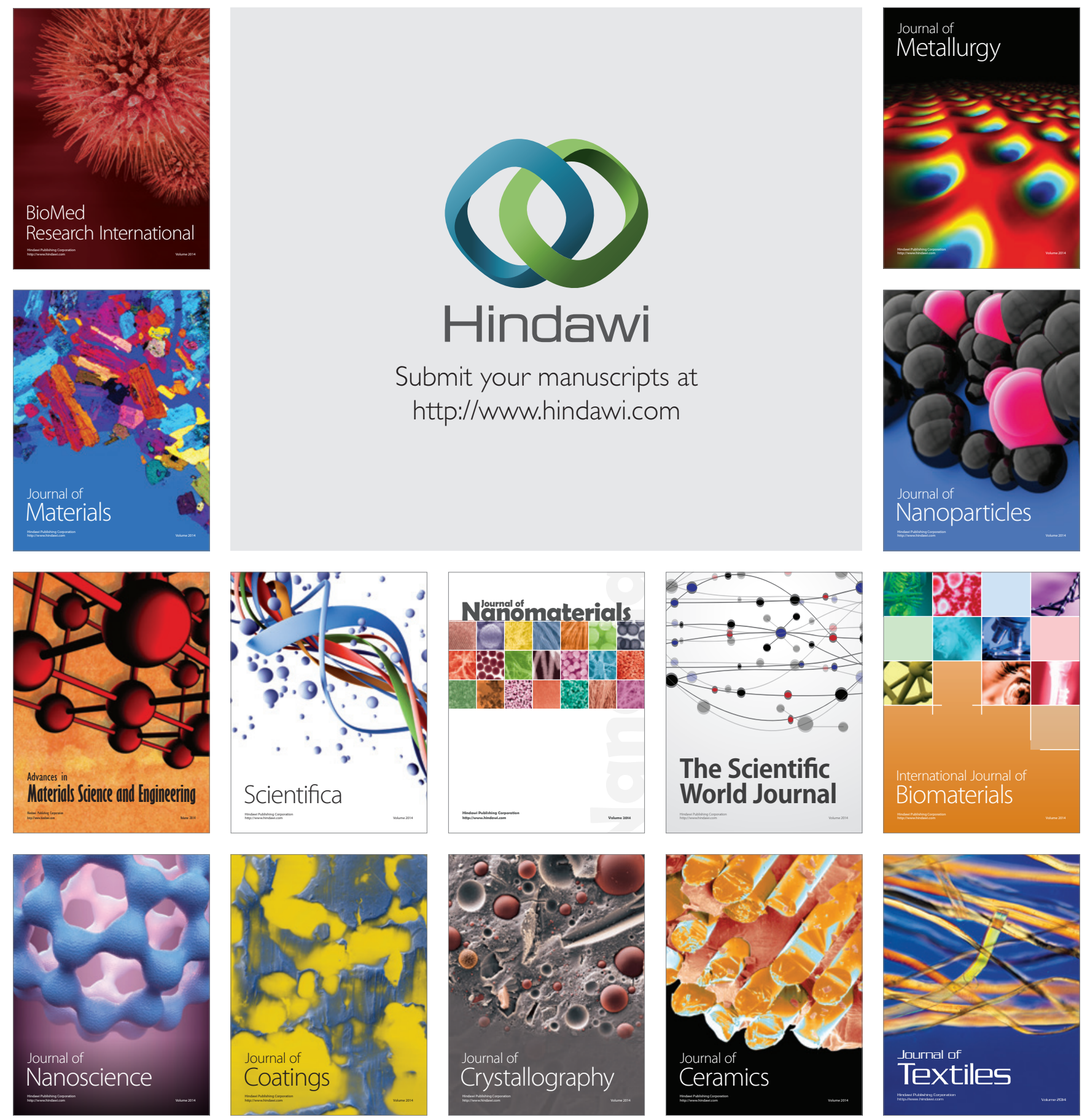